\title{
Breastfeeding and the risk of dental caries: a systematic review and meta-analysis
}

\author{
R Tham', G Bowatte', SC Dharmage ${ }^{1,2}$, DJ Tan ${ }^{1,3}$, MXZ Lau', X Dai', KJ Allen ${ }^{2,4}$, CJ Lodge (clodge@unimelb.edu.au) ${ }^{1,2}$ \\ 1.Allergy and Lung Health Unit, Centre for Epidemiology and Biostatistics, Melbourne School of Population and Global Health, The University of Melbourne, Carlton, Vic., Australia \\ 2.Murdoch Childrens Research Institute and University of Melbourne Department of Paediatrics, Royal Children's Hospital, Parkville, Vic., Australia \\ 3.NHMRC Centre of Research Excellence for Chronic Respiratory Disease, School of Medicine, University of Tasmania, Hobart, TAS, Australia \\ 4.Institute of Inflammation and Repair, University of Manchester, UK
}

\section{Keywords}

Breastfeeding, Child, Dental caries, Meta-analysis, Systematic review

\section{Correspondence}

Caroline Lodge MBBS Grad Di Epi PhD, Allergy and Lung Health Unit (ALHU), Centre for Epidemiology and Biostatistics, School of Population \& Global Health, Faculty of Medicine, Dentistry \& Health Sciences, The University of Melbourne, Level 3, 207 Bouverie Street, Melbourne, Vic. 3010, Australia. Tel: +61383440848 |

Fax: +61393495815

Email: clodge@unimelb.edu.au

\section{Received}

18 May 2015; revised 10 June 2015;

accepted 7 July 2015.

DOI:10.1111/apa.13118

\begin{abstract}
Aim: To synthesise the current evidence for the associations between breastfeeding and dental caries, with respect to specific windows of early childhood caries risk.
\end{abstract}

Methods: Systematic review, meta-analyses and narrative synthesis following searches of PubMed, CINAHL and EMBASE databases.

Results: Sixty-three papers included. Children exposed to longer versus shorter duration of breastfeeding up to age 12 months (more versus less breastfeeding), had a reduced risk of caries (OR 0.50; 95\% $0.25,0.99, \mathrm{I}^{2} 86.8 \%$ ). Children breastfed $>12$ months had an increased risk of caries when compared with children breastfed $<12$ months (seven studies (OR 1.99; 1.35, 2.95, I 69.3\%). Amongst children breastfed $>12$ months, those fed nocturnally or more frequently had a further increased caries risk (five studies, OR 7.14; $3.14,16.23, I^{2} 77.1 \%$ ). There was a lack of studies on children aged $>12$ months simultaneously assessing caries risk in breastfed, bottle-fed and children not bottle or breastfed, alongside specific breastfeeding practices, consuming sweet drinks and foods, and oral hygiene practices limiting our ability to tease out the risks attributable to each.

Conclusion: Breastfeeding in infancy may protect against dental caries. Further research needed to understand the increased risk of caries in children breastfed after 12 months.

\section{INTRODUCTION}

Dental caries (tooth decay) is a major public health problem affecting $60-90 \%$ of school-aged children (1), with increased prevalence in children from lower socio-economic groups (2). It is caused by multi-factorial and complex interactions between cariogenic bacteria in the mouth with dietary carbohydrates that produce acids and demineralise the teeth (2). The pain and infection caused by dental caries can be extremely distressing and can impact on quality of life and ability to function (3), lead to lost productivity and involve high health care costs (4) including general anaesthesia for treatment of severe cases. This accounts for one of the most common causes of child hospitalisation in industrialised countries (5) and is among the most common causes of avoidable child hospitalisations (6). Early loss of deciduous dentition can lead to ongoing dental problems in the permanent dentition.

The evidence concerning infant feeding as a risk factor for dental caries is inconsistent. Dental caries risk is related

\footnotetext{
Abbreviations

95\%CI, 95\% Confidence Intervals; NOS, Newcastle Ottawa Scale; OR, Odds ratio; RCT, Randomized controlled trials; RR, Relative risk; WHO, World Health Organization.
}

to the carbohydrate content of breast milk or formula along with factors which determine the length of contact between breast milk or formula and the erupted dentition (i.e. frequency of feeding, and feeding practices which result in pooling of breast milk or formula around the teeth surfaces, such as feeding babies to sleep). The central determinant of caries risk, however, is the age of colonisation and levels of cariogenic bacteria (e.g. Streptococcus mutans) (7) in an infant's mouth. Earlier and denser oral colonization by cariogenic bacteria are related to increased caries risk (8). Breast milk, in contrast to formula, contains breast-specific

\section{Key notes}

- Children exposed to more versus less breastfeeding up to 12 months had reduced risk of dental caries.

- Increased risk of dental caries in children breastfed $>12$ months, especially if frequent or nocturnal, may be due to unmeasured confounders including dietary sugars and oral hygiene practices.

- Research should simultaneously investigate breastfeeding practices including frequency and nocturnal routines, along with dietary and oral hygiene practices to more accurately determine specific risks. 
Lactobacilli and substances, including human casein and secretory IgA, which inhibit the growth and adhesion of cariogenic bacteria, particularly oral Streptococci $(9,10)$. The risk of dental caries is also dependent on the presence of teeth and rises with increasing number of teeth. Risk also changes as the infant's diet starts to include foods and drinks other than breast milk or formula, depending on the carbohydrate content, acidity and consumption frequency of the introduced diet.

The important aspect of timing of tooth eruption for our systematic review is that the deciduous teeth most at risk of early childhood caries (eight upper and lower central and lateral incisors) start to erupt at 6 months and are fully erupted by 12 months. The next most vulnerable deciduous teeth (four upper and lower first molars) erupt between 13 and 19 months, the remainder are erupted by 33 months (11).

Current WHO breastfeeding guidelines recommend exclusive feeding for the first 6 months of life and complementary breastfeeding up to 2 years (12). Although the UNICEF calculated global prevalence of breastfeeding at 12 months from 62 countries is $74 \%$, this figure hides the underlying heterogeneity between countries (13). As opposed to low income countries, the duration of total breastfeeding in high/middle income countries is shorter with only $21 \%$ of US mothers breastfeeding at 12 months (14) and similar rates in the UK (13), Canada (5) and Australia (15). National guidelines in high/middle income countries, where the risk of infant morbidity and mortality from gastrointestinal disease is relatively low, recommend breastfeeding for at least 12 months (16). Thus, investigating windows of exposure before and after 12 months of age is relevant to breastfeeding guidelines and practices as well as timing of tooth eruption.

The relationship between breastfeeding and dental caries has been systematically (17) and narratively reviewed (1820) with conflicting results between studies. There is controversy about what constitutes the best form of infant feeding to prevent dental caries and promote optimal dental health (21). Consequently no definitive optimal weaning times or breastfeeding practices have been determined to specifically address the risk of dental caries.

\section{AIM}

To summarise the current evidence for the association between breastfeeding and dental caries with specific reference to exposure windows and breastfeeding practices.

\section{METHODS}

\section{Search strategy}

We identified human English language studies through systematically searching electronic databases: PubMed Central, CINAHL and EMBASE from inception to the present. Our exposure of interest was breastfeeding as compared to formula or other feeding. Our outcome of

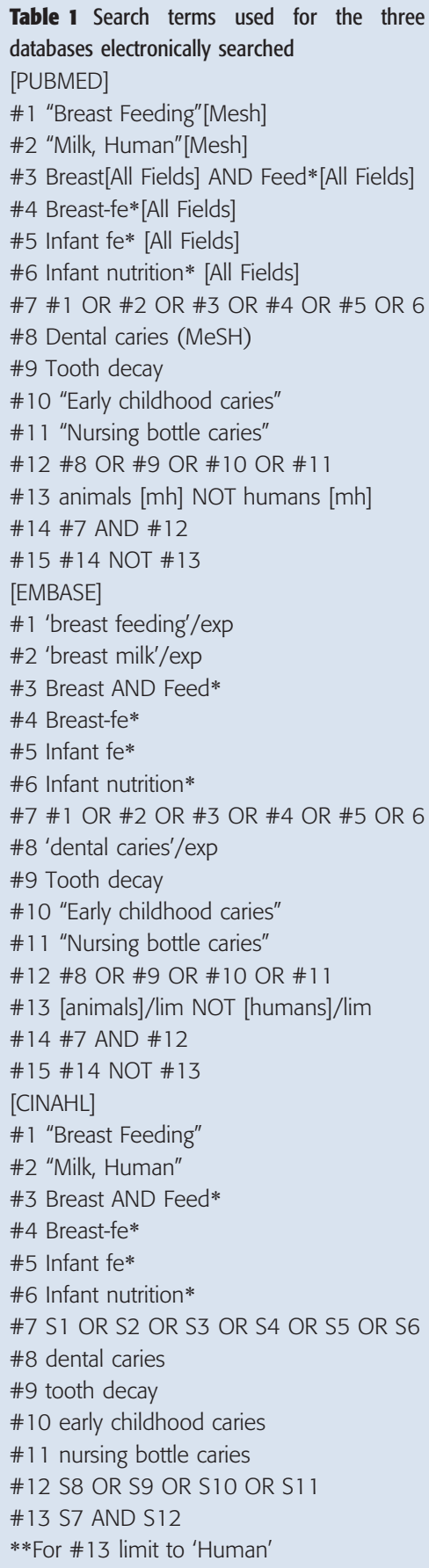

interest was the development of dental caries in deciduous or permanent teeth. An extensive list of search terms was used and is reported in Table 1 .

We checked reference lists of all primary studies and review articles for additional references. The titles and abstracts were independently reviewed for initial inclusion by two researchers (RT and GB). Disagreement was resolved by discussion and if consensus could not be reached, a third author (CL) made the final decision. 


\section{Eligibility criteria}

We included observational and experimental studies published in full text. We included children and adolescents from both general and high-risk populations (e.g. low socioeconomic communities). Dental caries as reported by appropriately qualified practitioner/researchers, a parent or through health records databases were included. We excluded participants who were born prematurely ( $<36$ weeks gestation) because these infants are often fed by other sources and can have complicated medical interventions.

\section{Assessment of quality and risk of bias}

Two researchers (RT and GB) independently conducted a quality assessment of each study using the NewcastleOttawa Scale (NOS) (22). Study quality was graded on a scoring system (see Tables 2-5 for key criteria). Differences in assessment and grading were resolved by discussion with a third researcher (CL).

The assessment of risk of bias was guided by the GRADE system for rating the quality of the evidence of observational studies (23).

Literature review identified key confounders that should be controlled for in breastfeeding and dental caries studies: socio-economic status, age, mother's educational level, number of teeth, and exposure to sugar in the diet (food or other liquid).

\section{Data extraction}

We extracted: study design; study country; age range of children; number of children; exposure and outcome definitions; how the outcome data were measured; effect estimates; confounders included in analysis; sub-group analysis; interactions; and findings.

\section{Assessment for meta-analysis}

Exposure and outcome definitions and effect estimates (odds ratios (OR), relative risks, prevalence ratios) with 95\% Confidence Interval $(95 \% \mathrm{CI})$ were abstracted where available for inclusion in a meta-analysis. Given the biological plausibility of the potential associations, we aimed to assess exposure to breastfeeding in two specific time windows: (i) Up to 12 months of age (upper and lower incisors present) and (ii) Beyond 12 months of age (other teeth erupting up to 33 months- increased risk of caries). As there were very few mothers who exclusively breastfed infants until 12 months or beyond, within these time windows we categorized studies into: (i) Never breastfed compared to any breastfeeding and (ii) More versus less breastfeeding. This category was created to include all

\begin{tabular}{|c|c|c|c|c|c|c|c|c|c|}
\hline RCT & Representativeness & $\begin{array}{l}\text { Selection of } \\
\text { non- exposed } \\
\text { cohort }\end{array}$ & $\begin{array}{l}\text { Ascertainment } \\
\text { of exposure }\end{array}$ & $\begin{array}{l}\text { Outcome of } \\
\text { interest not } \\
\text { present at start }\end{array}$ & Comparability & $\begin{array}{l}\text { Assessment } \\
\text { of outcome }\end{array}$ & $\begin{array}{l}\text { Adequate } \\
\text { follow up time }\end{array}$ & $\begin{array}{l}\text { Adequate } \\
\text { follow up } \\
\text { of cohorts }\end{array}$ & Score/10 \\
\hline Feldens et al. (30) & * & * & * & * & & $* *$ & * & * & 8 \\
\hline Feldens et al. (27) & * & * & * & * & & ** & * & * & 8 \\
\hline
\end{tabular}

\begin{tabular}{|c|c|c|c|c|c|c|c|c|c|}
\hline Cohort studies & Representativeness & $\begin{array}{l}\text { Selection of } \\
\text { non-exposed } \\
\text { cohort }\end{array}$ & $\begin{array}{l}\text { Ascertainment } \\
\text { of exposure }\end{array}$ & $\begin{array}{l}\text { Outcome of } \\
\text { interest not } \\
\text { present at start }\end{array}$ & Comparability & $\begin{array}{l}\text { Assessment } \\
\text { of outcome }\end{array}$ & $\begin{array}{l}\text { Adequate } \\
\text { follow } \\
\text { up time }\end{array}$ & $\begin{array}{l}\text { Adequate follow } \\
\text { up of cohorts }\end{array}$ & Score/10 \\
\hline Feldens et al. (25) & $*$ & $*$ & * & * & $* *$ & $* *$ & * & $*$ & 10 \\
\hline Chaffee et al. (26) & $*$ & $*$ & * & * & $*$ & * & $*$ & $*$ & 8 \\
\hline Hong et al. (31) & $*$ & $*$ & & * & $* *$ & $* *$ & $*$ & & 8 \\
\hline Kramer et al. (29) & $*$ & $*$ & * & * & & $* *$ & * & * & 8 \\
\hline Kramer et al. (28) & $*$ & $*$ & $*$ & * & & $* *$ & * & * & 8 \\
\hline Ollila (38) & $*$ & $*$ & & * & & $* *$ & * & * & 7 \\
\hline Silver (32) & & $*$ & * & & & $*$ & $*$ & $*$ & 5 \\
\hline Tada et al. (33) & & $*$ & & & & $*$ & $*$ & $*$ & 5 \\
\hline Tanaka et al. (34) & $*$ & $*$ & & $*$ & $* *$ & $* *$ & $*$ & & 8 \\
\hline Thitasomakul et al. (35) & $*$ & $*$ & * & * & & $* *$ & $*$ & & 7 \\
\hline $\begin{array}{l}\text { van Palenstein } \\
\text { Helderman et al. (36) }\end{array}$ & & $*$ & * & & & $* *$ & $*$ & $*$ & 6 \\
\hline Yonezu et al. (37) & & $*$ & & & & $* *$ & $*$ & * & 5 \\
\hline
\end{tabular}




\begin{tabular}{|c|c|c|c|c|c|c|c|c|c|}
\hline Case control & $\begin{array}{l}\text { Adequate } \\
\text { case definition }\end{array}$ & $\begin{array}{l}\text { Representativeness } \\
\text { of cases }\end{array}$ & $\begin{array}{l}\text { Selection of } \\
\text { controls }\end{array}$ & $\begin{array}{l}\text { Definition of } \\
\text { controls }\end{array}$ & Comparability & $\begin{array}{l}\text { Ascertainment } \\
\text { of exposure }\end{array}$ & $\begin{array}{l}\text { Method of } \\
\text { ascertainment }\end{array}$ & $\begin{array}{l}\text { Nonresponse } \\
\text { rate }\end{array}$ & Score/10 \\
\hline Bahuguna et al. (39) & * & & & $*$ & * & & $*$ & * & 5 \\
\hline Matee et al. (40) & $*$ & & $*$ & $*$ & & & $*$ & & 4 \\
\hline Roberts et al. (41) & & & * & * & ** & & & * & 5 \\
\hline
\end{tabular}

studies, which compared groups with relatively more (longer duration of breastfeeding) and relatively less breast milk exposure (shorter duration). To choose between multiple reported ORs for a single study we preferentially selected: estimates for exclusive breastfeeding or, if not available, any breastfeeding; then the longest duration compared with the shortest. If there were multiple ages of outcome within the particular group then we chose the oldest age reported.

We performed meta-analysis if there were three or more studies in each time window and category of breastfeeding. Random effects meta-analyses were performed if the heterogeneity $\left(\mathrm{I}^{2}\right)$ was $>25 \%$. Heterogeneity was considered to be high, and results unreliable if $\mathrm{I}^{2}$ values were $>75 \%$. We were unable to quantitatively assess for publication bias as no group contained more than 10 studies. Studies not meeting these criteria were qualitatively assessed.

Statistical analysis was performed using Stata IC 13 (StataCorp., LP Texas, USA).

\section{RESULTS}

\section{Search results}

Electronic literature search (2 October 2014) and manual search found 480 peer-reviewed scientific articles after duplicate papers were removed. Of these, 366 were excluded after abstract review for failing to meet the eligibility criteria. A large number of these papers were not related to breastfeeding or dental caries, were not in English or were not original research. Of the remaining 114 full text articles, 51 were excluded as: (i) they did not assess the relevant exposure (breastfeeding) and outcome (dental caries) or (ii) all feeding types were analysed together or (iii) data were duplicated in more than one paper or (iv) no analysis was reported or studies lacked control or comparator groups [Fig. 1 (24)]. In total 63 papers were included.

\section{Characteristics of included studies}

Although the 63 papers did not include randomised controlled trials (RCT) of breastfeeding, six cohort studies (25-30) were nested within RCTs of breastfeeding promotion interventions. There were eight additional cohort studies (31-38) and three case-control studies (39-41). The remaining 46 studies were cross-sectional in design (42-86). The studies were predominantly conducted in high and middle income countries with only eight studies from low income countries (87). All caries outcomes were assessed by dental professionals through oral examination. Key characteristics are summarised in the Appendix.

\section{Quality assessment}

Tables 2 3, 4, and 5 detail the NOS score assigned to each included study. The cohort and cross-sectional studies that were embedded in RCTs of a range of breastfeeding promotion interventions (25-30) scored highly as the study designs overcame many sources of bias and reporting limitations that were apparent in the other cohort, case-control and cross-sectional studies. Other cohort studies were weakened by the method used to ascertain infant feeding practices (self-report) which subjected them to recall bias, recruitment of children through oral health services (selection bias), lack of reporting of the absence of caries at the commencement of the study (ascertainment bias), loss to follow -up and accounting for these participants (attrition bias), and lack of controlling for confounders. Case-control study designs were inherently subject to recall bias when ascertaining infant feeding practices. Furthermore, cases and controls were not representative of the broader population as they were recruited in settings where children were likely to have caries. Selection bias was also a problem as the selection of controls was not clearly described. Crosssectional studies were the weakest but most common study design. The studies which scored $<4$ were classified as unsatisfactory due to major limitations in study design and reporting. Studies that scored 4 were classified as satisfactory, however, all of these studies lacked consideration of key confounders. In the higher quality studies $(\geq 5)$ there were limitations in how exposure was ascertained as many studies used self-report questionnaires (recall bias).

\section{Meta-analysis}

We meta-analysed the small number of studies which included statistical effect measures.

\section{Breastfeeding up to 12 months of age}

One prospective cohort (34) and four cross-sectional studies $(48,52,59,70)$ reported odds ratios for the association between children who were exposed to more versus less breastfeeding up to 12 months (OR 0.50; 0.25-0.99, I ${ }^{2}$ $86.8 \%$ ) (Fig. 2). There were not enough studies to perform metaregression for formal investigation of this heterogeneity. There appeared to be differences, however, based on the comparison groups of the included studies. The two studies 
Table 5 Newcastle-Ottawa Scale Quality Assessment score for Cross-sectional Studies

\begin{tabular}{|c|c|c|c|c|c|c|}
\hline Cross-sectional & Representativeness & $\begin{array}{l}\text { Selection of non- } \\
\text { exposed cohort }\end{array}$ & $\begin{array}{l}\text { Ascertainment } \\
\text { of exposure }\end{array}$ & Comparability & $\begin{array}{l}\text { Assessment } \\
\text { of outcome }\end{array}$ & Score/7 \\
\hline Alaluusua et al. (42) & & $*$ & $*$ & & * & 3 \\
\hline al-Dashti et al. (43) & & $*$ & $*$ & & $* *$ & 4 \\
\hline Azevedo et al. (44) & $*$ & $*$ & $*$ & & $* *$ & 5 \\
\hline Campus et al. (45) & $*$ & $*$ & & $* *$ & * & 5 \\
\hline Cariño et al. (46) & & $*$ & & & $* *$ & 3 \\
\hline Dini (47) & $*$ & $*$ & & $*$ & $*$ & 4 \\
\hline Du et al. (48) & & $*$ & & $* *$ & * & 4 \\
\hline Dye et al. (49) & $*$ & $*$ & & $* *$ & $* *$ & 6 \\
\hline Folayan et al.(50) & & $*$ & $*$ & $*$ & & 3 \\
\hline Folayan et al. (87) & & $*$ & $*$ & & $*$ & 3 \\
\hline Forsman et al. (51) & & $*$ & $*$ & & $*$ & 3 \\
\hline Hallett et al. (52) & $*$ & $*$ & & $* *$ & $* *$ & 6 \\
\hline Hallonsten et al. (53) & & $*$ & $*$ & & * & 3 \\
\hline Haq et al. (54) & & & $*$ & & * & 2 \\
\hline Hardy (55) & $*$ & & & & & 1 \\
\hline Harrison et al. (56) & & $*$ & $*$ & & $* *$ & 4 \\
\hline Holt et al. (57) & & $*$ & $*$ & & $*$ & 3 \\
\hline Hong et al. (58) & $*$ & $*$ & 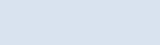 & $* *$ & $*$ & 5 \\
\hline lida et al. (59) & $*$ & $*$ & $*$ & $*$ & $*$ & 5 \\
\hline Johansson et al. (60) & & $*$ & $*$ & & * & 3 \\
\hline Livny et al. (61) & & $*$ & $*$ & & $*$ & 3 \\
\hline Majorana et al. (62) & $*$ & $*$ & & & $* *$ & 4 \\
\hline Masumo et al. (63) & $*$ & $*$ & $*$ & & $* *$ & 5 \\
\hline Mattos-Graner et al. (64) & & $*$ & $*$ & & $* *$ & 4 \\
\hline Nobile et al. (65) & & $*$ & & * & $*$ & 3 \\
\hline Nunes et al. (66) & & $*$ & . & $* *$ & $* *$ & 5 \\
\hline Perera et al. (67) & & $*$ & * & & $*$ & 3 \\
\hline Prakash et al. (68) & $*$ & $*$ & $*$ & & * & 4 \\
\hline Prakasha Shrutha et al. (69) & $*$ & $*$ & & & & 2 \\
\hline Qadri et al. (70) & $*$ & $*$ & $*$ & & $*$ & 4 \\
\hline Retnakumari (71) & & $*$ & * & & $*$ & 3 \\
\hline Rosenblatt (72) & & $*$ & $*$ & & $*$ & 3 \\
\hline Sankeshwari et al. (73) & $*$ & $*$ & & & * & 3 \\
\hline Santos (74) & & $*$ & & & $*$ & 2 \\
\hline Sayegh et al. (75) & $*$ & $*$ & & & $* *$ & 4 \\
\hline Sayegh et al. (76) & $*$ & $*$ & & $*$ & $* *$ & 5 \\
\hline Serwint et al. (77) & & $*$ & $*$ & & * & 3 \\
\hline Slabsinskiene et al. (78) & $*$ & $*$ & & & * & 3 \\
\hline Songo et al. (79) & & $*$ & & & * & 2 \\
\hline Tanaka, (80) & $*$ & $*$ & & $* *$ & * & 5 \\
\hline Tiano et al. (81) & & $*$ & $*$ & & * & 3 \\
\hline Tyagi, (82) & & & & & * & 1 \\
\hline Vachirarojpisan et al. (83) & $*$ & $*$ & $*$ & $*$ & $*$ & 5 \\
\hline Vazquez-Nava et al. (84) & $*$ & $*$ & & $* *$ & * & 5 \\
\hline Wendt (85) & $*$ & $*$ & $*$ & & $*$ & 4 \\
\hline Yonezu et al. (86) & & $*$ & & & & 1 \\
\hline
\end{tabular}

which compared ever breastfeeding in the first 12 months with never breastfeeding $(48,70)$, both showed a marked protective effect of breastfeeding on dental caries compared with other feeding. Whereas the three studies which compared a longer duration of breastfeeding in the first 12 months to a comparison group which included children who had had some exposure to breastfeeding did not $(34,52,59)$. A meta-analysis on this three study subgroup found an OR of 0.92; 0.69-1.23, $\mathrm{I}^{2} 0 \%$ (Fig. 3).

\section{Breastfeeding after 12 months of age}

Two cohort studies $(33,34)$, one case control study (40) and four cross-sectional studies $(52,65,75,78)$ reported odds ratios for the association between more or less breastfeeding after the age of 12 months and dental caries. The comparison groups for these studies included both those who had never been breastfed and those who had been breastfed for shorter durations. The pooled estimate was OR 1.99; 1.35-2.95, I² 69.3\% (Fig. 4). 


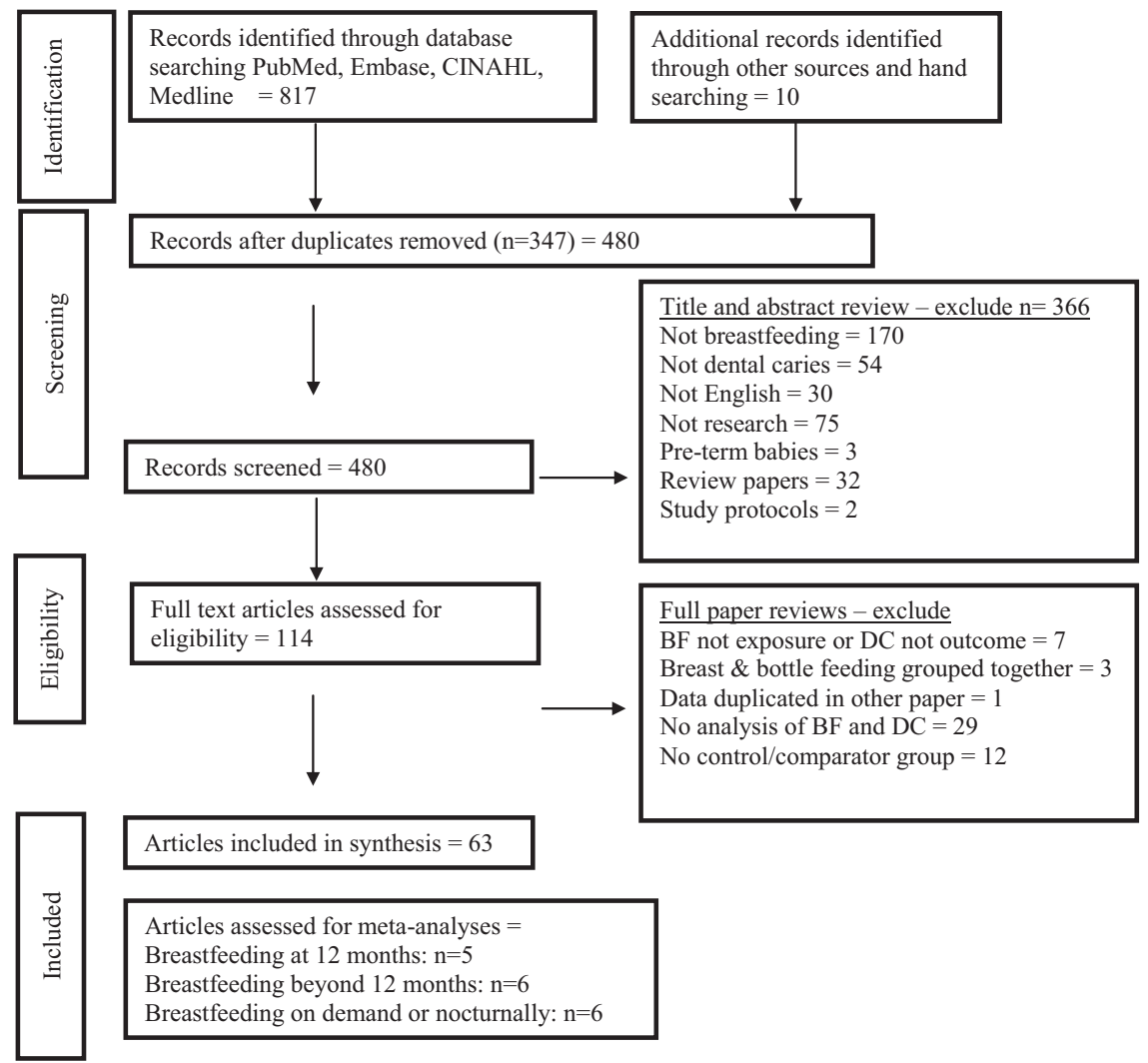

Figure 1 PRISMA Flow diagram of review.

Only two studies $(26,80)$ reported prevalence ratios so these could not be meta-analysed.

\section{Nocturnal breastfeeding in those breastfed longer than 12 months}

One cohort (36), one case-control (40) and three crosssectional studies $(67,84,86)$ reported odds ratios for the association between more versus less nocturnal breastfeeding and the risk of dental caries amongst the subgroup of children breastfed longer than 12 months. The pooled estimate was OR 7.14; 3.14-16.23, $\mathrm{I}^{2} 77.1 \%$ (Fig. 5).

\section{Narrative synthesis}

The majority of studies $(n=46)$ were not included in the meta-analyses due to methodological differences in the measures of exposure and outcomes, or reporting of correlational analyses only.

\section{Studies embedded in randomised controlled trials (RCTs)}

It is not ethical to conduct randomized trials assigning participants to breastfeeding and non-breastfeeding groups in order to more definitively assess the association between breastfeeding and dental caries. However, a number of RCTs have been conducted that investigated the impact of breastfeeding promotion programmes (25-30). In a RCT of an intervention that provided monthly advice on healthy feeding practices over 12 months via home visits in Brazil
$(25,27,30)$ the intervention group demonstrated a lower incidence of caries at 12 months (OR $=0.52,0.27-0.97$, $\mathrm{p}=0.03)$ and 4 years $(\mathrm{RR}=0.78,0.65-0.93, \mathrm{p}=0.004)$. Investigating breastfeeding frequency at 12 months, the study also found a doubled risk of caries when feeding frequency was 3-6 times/day $(\mathrm{RR}=2.04,1.22-3.39$, $\mathrm{p}=0.000)$ and $\geq 7$ times/day $(\mathrm{RR}=1.97,95 \% \mathrm{CI} 1.45$ $2.68, \mathrm{p}=0.000$ ) compared to $0-2$ times/day. Analyses were adjusted for maternal schooling level, daily meals, bottle use for fruit juice/soft drinks, consumption of high density sugar and number of teeth. Another birth cohort study nested in an intervention conducted through maternal health centres in Brazil (26) found that, in adjusted regression models, as breastfeeding continued beyond 6 months the prevalence ratio of caries in breastfed children increased (compared to breastfeeding $<6$ months) but was only significant when still breastfeeding at $\geq 24$ months: $6-11$ months $(\mathrm{PR}=1.45,95 \%$ CI 0.83-2.53); 12-23 months $(\mathrm{PR}=1.39$, 95\%CI 0.73 $2.64) ; \geq 24$ months $(\mathrm{PR}=1.85,95 \% \mathrm{CI} 1.11-3.08)$. A birth cohort study nested in a breastfeeding promotion intervention in Belarus found no significant difference in caries incidence or prevalence in the intervention group when children were aged 6.5 years $(28,29)$.

\section{Breastfed versus formula fed}

Studies that examined ever versus never breastfed children reported a range of findings. Six cross-sectional studies 


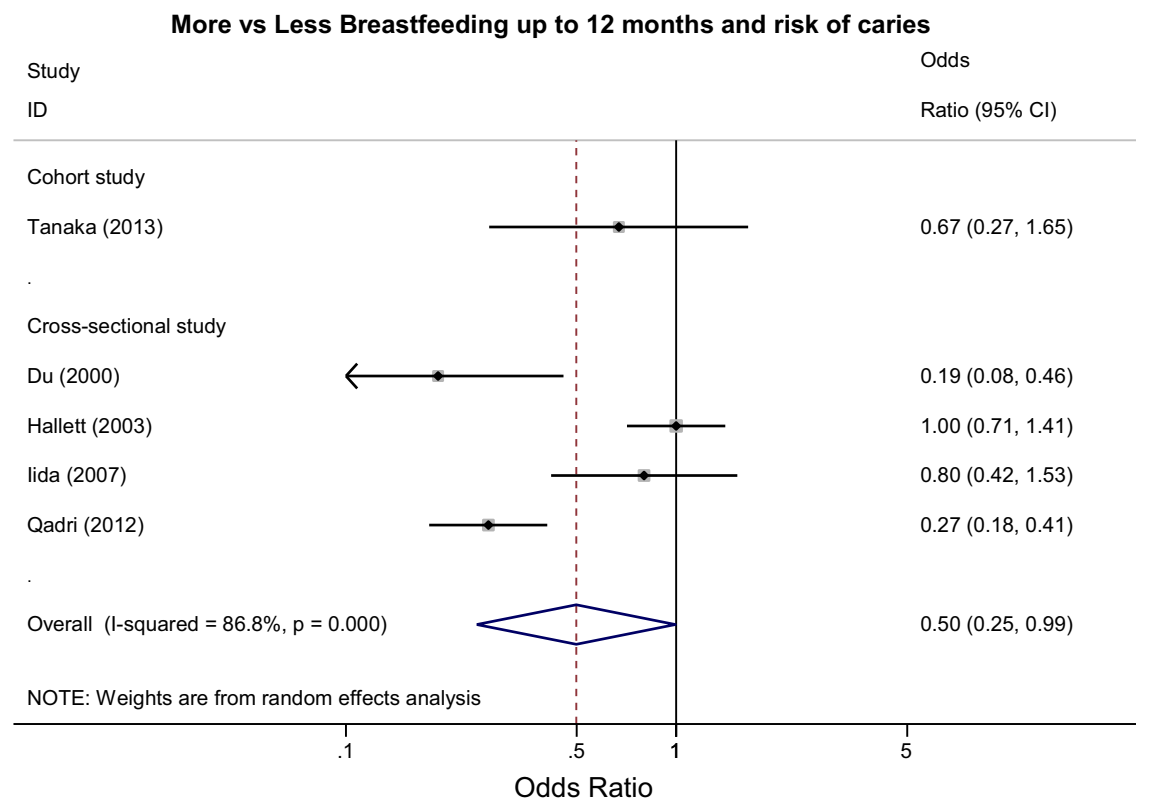

Figure 2 More versus Less breastfeeding (including never breastfed) up to 12 months of age and the risk of dental caries

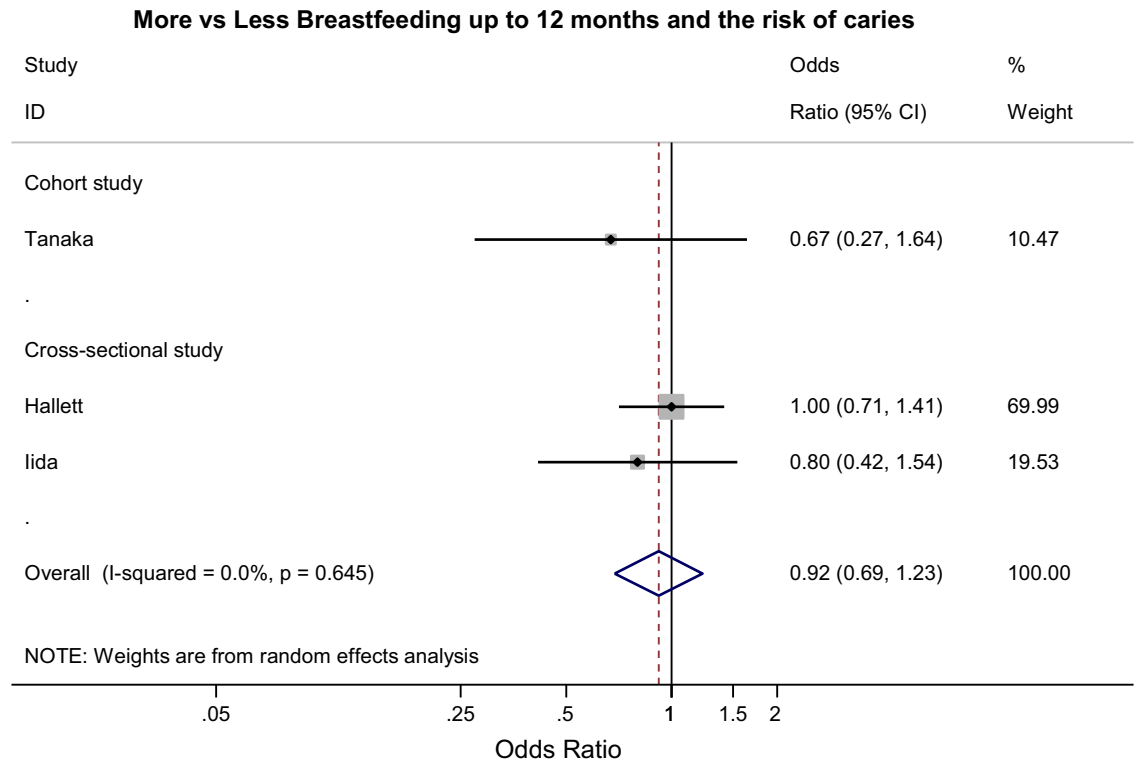

Figure 3 More versus Less Breastfeeding (excluding never breastfed) up to 12 months of age and the risk of dental caries.

reported no significant difference in the prevalence of caries between the two groups $(49,61,72-74,83)$; one cohort and one cross-sectional study reported significantly lower caries in breastfed children $(32,57)$; one cross-sectional study found a lower adjusted caries risk in breastfed versus bottlefed children $(\mathrm{OR}=0.61,95 \% \mathrm{CI} 0.39-0.97, \mathrm{p}=0.038)(70)$; one cohort study reported higher caries increment in breastfed children between 12 to 18 months but the association disappeared in the multivariate analysis (35); one cross-sectional study reported an increased risk of dental caries in ever breastfed children of borderline significance $(\mathrm{p}=0.08)(77)$; and one cross-sectional study found a lower adjusted caries risk in breastfed versus bottlefed children.

\section{Breastfeeding duration}

Three of four cohort studies found that breastfeeding beyond 12 months was correlated or associated with increased caries 


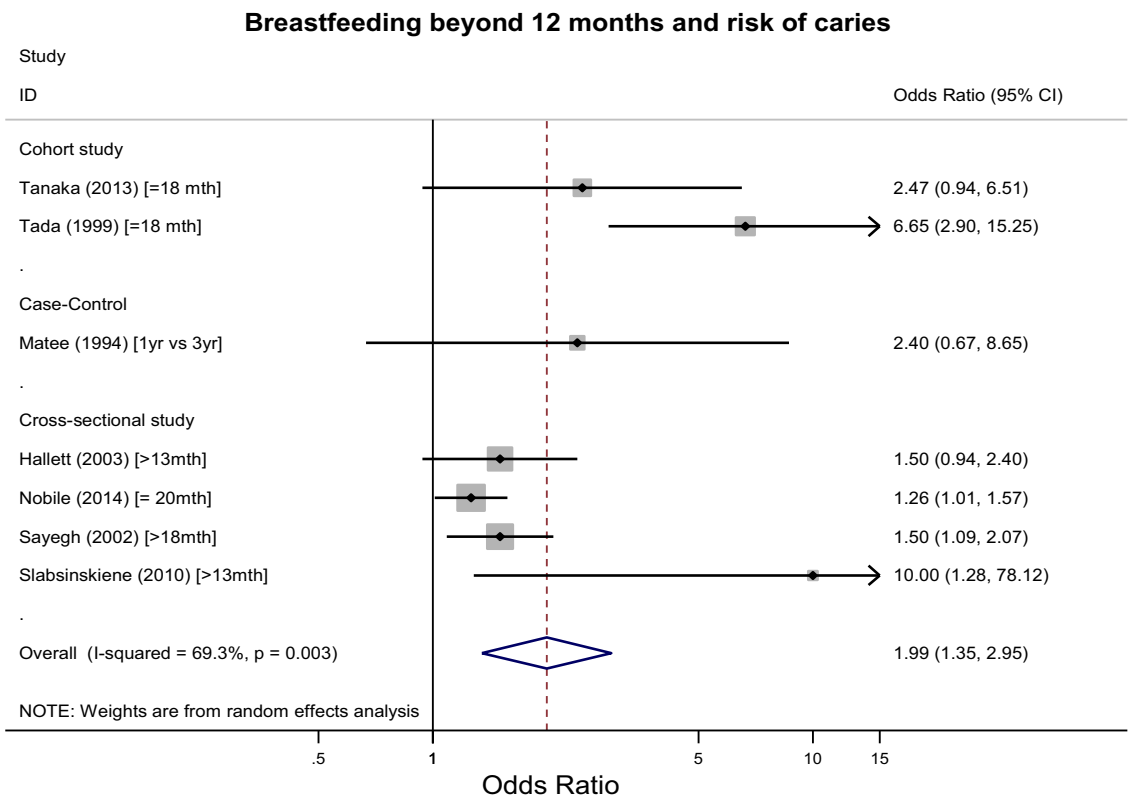

Figure 4 Breastfeeding beyond 12 months and the risk of dental caries.

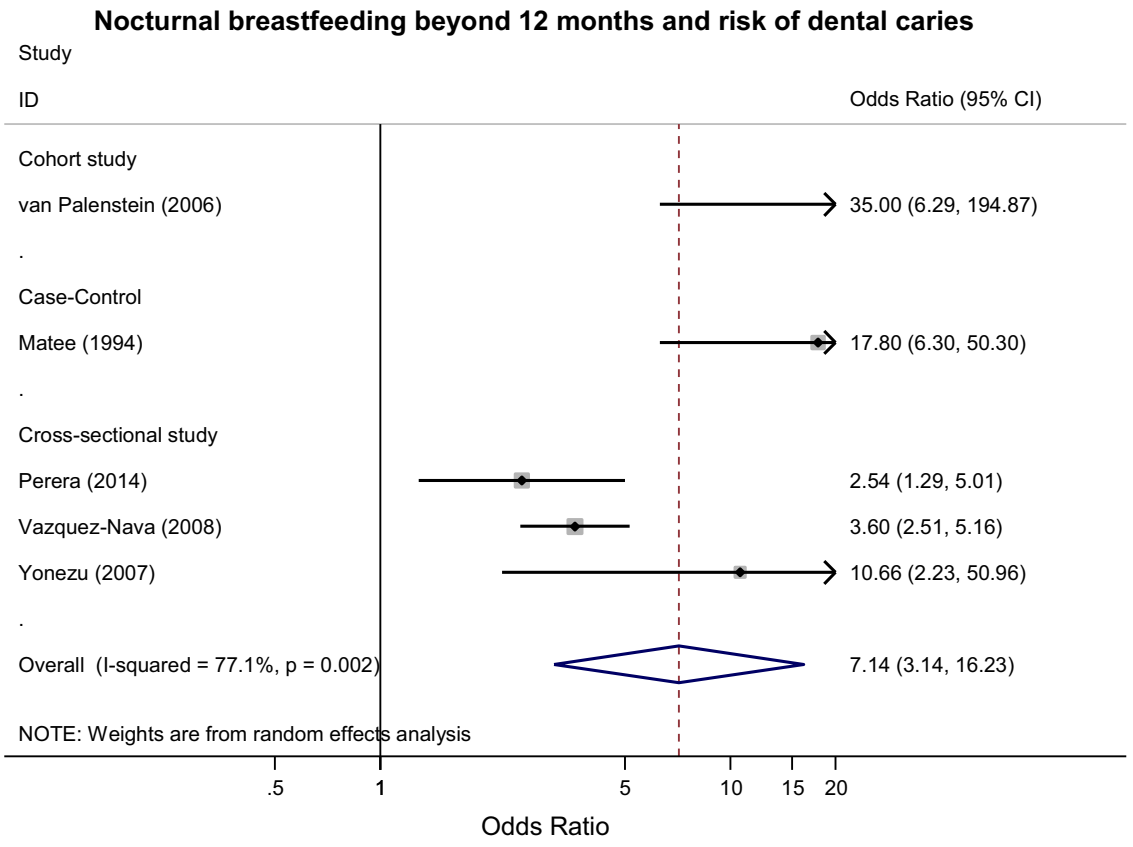

Figure 5 More versus Less nocturnal breastfeeding and the risk of dental caries in those breastfed longer than 12 months.

prevalence compared with shorter durations of breastfeeding. Chaffee et al. (26) found that the adjusted prevalence ratio of caries in children breastfed $\geq 24$ months was 2.1 (95\%CI 1.5-3.25) compared to children breastfed $<6$ months. Yonezu et al. (37) found significantly more caries in children breastfed $>18$ months than those weaned $<18$ months. Feldens et al. (25) found the risk of caries rose in children breastfed beyond 12 months. Ollila et al.'s (38) survival analysis found no difference between children breastfed $>12$ months and those not. Cross-sectional studies reported variable findings: increased caries prevalence in children breastfed longer than those breastfed for shorter times $(44,45,53,54,63,65,71,75,78,81,85)$; and no difference in caries prevalence between duration groups $(66,82)$. 
The few studies that controlled for confounding factors found decreased caries risk with shorter breastfeeding duration (6-12 months) compared to longer duration $(>13$ months) $(26,34,45,76,80)$ and increased risk of caries if breastfed $<6$ months $(31,48)$.

\section{Breastfeeding on demand and nocturnally}

In addition to the meta-analysed studies, a number of crosssectional studies reported significant correlations between infants/children breastfed during the night $(44,67)$, on demand (68) or sleeping with a nipple in the mouth $(60,71,76)$ and increased prevalence of dental caries. One cohort study found an increased adjusted risk of dental caries with increased daily breastfeeding frequency including nocturnal feeding (25).

\section{DISCUSSION}

Qualitative assessment of studies investigating breastfeeding up to 12 months of age suggested that children who were exposed to more breastfeeding (longer duration) compared to less or no breastfeeding were protected from dental caries. Meta-analysis of five studies also found reduced risk of dental caries in children breastfed more versus less up to 12 months, however, the heterogeneity between studies was too high to make the estimate reliable. In contrast, children who were breastfed beyond 12 months had an increased prevalence of dental caries. Amongst those who continued to be breastfed after 12 months, there was a further increased risk of caries in children who were breastfed nocturnally.

Three elements are essential for dental caries to occur: a tooth, cariogenic bacteria (e.g. Streptococcus mutans) and substrate for the bacteria (sugar) (2). The risk of developing dental caries changes as factors associated with each element change. The first tooth usually erupts in an infant's mouth between 6 and 12 months of age. As each tooth erupts the risk of developing dental caries increases, hence age and number of teeth increases risk. Cariogenic bacteria are transmitted to the child via close contact with the mother's saliva (88) but their levels and cariogenicity vary between individuals (2) depending on maternal bacterial levels, maternal caries prevalence, oral hygiene practices and exposure to dietary sugars (21). Breast milk is known to contain immunomodulatory factors along with a rich microbiome which is responsible for establishing normal intestinal flora (89). Initial protection from dental caries may be mediated through establishment of a healthy oral microbiome in infants through exposure to breastfeeding and contact with skin and breast milk microbiomes. Additionally, the child's oral microbiome changes over time with the emergence of new teeth. The essential substrates for cariogenic bacteria are simple carbohydrates (sugars) which can be in a range of forms (e.g. lactose, sucrose, glucose). The longer these sugars are in contact with teeth, the higher the risk of dental caries. The amount of carbohydrate (cariogenicity) contained in the different milks and formulas may also help to explain the different results we found before and after 12 months of age. The cariogenicity of human breast milk has not been extensively examined under in vivo conditions, however animal studies suggest that at high frequency exposures, human breast milk has greater cariogenicity compared to bovine milk but less than infant formula $(90,91)$. Relative cariogenicity of breast milk will also depend on the comparison group. Below 12 months it is usual to feed infants either breast milk or formula which have around the same carbohydrate content. After 12 months, however, children in high income countries are often weaned onto cow's milk which has half the carbohydrate content of human milk. However, each element is subject to modification by risk factors such as socio-economic status, maternal educational level, maternal oral health, maternal smoking status, position in birth order, sugars in diet, oral hygiene and exposure to fluoride (2).

Breastfeeding duration, frequency of breastfeeding and nocturnal breastfeeding during sleep are most often analysed as separate breastfeeding behaviours, however they are inter-related. Nocturnal breastfeeding is often used to comfort an infant or child who may then fall asleep with the nipple in their mouth. In this position, the tongue fills the mouth and holds the breast milk against the surfaces of the teeth, thereby prolonging the exposure of the substrate to the cariogenic bacteria that are attached to the teeth surfaces and hence increasing the risk of dental caries. It is possible that children breastfed beyond 12 months are also engaging in nocturnal breastfeeding but the modification of dental caries risk by infant feeding practices has not been examined in depth in any of the studies included in this review. In addition, children $>12$ months are no longer being exclusively breast or bottle fed and the diet is expanding to include other fluids and solids. It has been reported that children who are breastfed for longer durations also have more frequent cariogenic food intakes $(25,53,58)$. Oral hygiene practices to remove bacterial plaque are important as more teeth erupt to reduce the risk of dental caries. Only a few studies included in this review controlled for key confounding factors and this may have resulted in an overestimation of the role of prolonged, frequent and nocturnal breastfeeding in the development of dental caries. Until the dietary and oral hygiene details of these children are controlled for we cannot be certain whether prolonged, frequent or nocturnal breastfeeding can be principally associated with early childhood caries.

This is the first systematic review of breastfeeding and dental caries that includes critical exposure windows, limited meta-analyses and a range of study types. We provide quantitative evidence that is suggestive of the potentially protective effects of breastfeeding from dental caries up to 12 months, but higher risk of dental caries in children breastfed beyond 12 months, frequently, and/or nocturnally. However, there is high heterogeneity between the studies included in the meta-analyses (possibly due to differing comparison groups) and lack of controlling for key confounders (e.g. other foods/drinks in the diet, oral 
hygiene, maternal oral health status) which limits the reliability of the results.

\section{CONCLUSION}

Breastfeeding up to 12 months of age is not associated with an increased risk of dental caries and in fact may offer some protection compared with formula. However, children breastfed beyond 12 months, a time during which all deciduous teeth erupt, had an increased risk of dental caries. This may be due to other factors which are linked with prolonged breastfeeding including nocturnal feeding during sleep, cariogenic foods/drinks in the diet, or inadequate oral hygiene practices. Further research with careful control of pertinent confounding factors is needed to elucidate this issue and better inform infant feeding guidelines. As per recommendations from previous reviews $(17,19)$, the introduction of food sources to infants should be low in simple carbohydrates (sugars) and oral hygiene practices should start with the eruption of the first tooth so that bacterial plaque is removed from tooth surfaces to reduce the risk of dental caries.

\section{CONFLICT OF INTEREST STATEMENT}

Preparation of the manuscript was assisted by funding from the WHO, which had no part in determining the outcomes or presentation of findings. None of the authors has any conflicts of interest to declare.

\section{References}

1. Petersen PE. The World Oral Health Report. In: World Health Organisation, editor Continuous improvement of oral health in the 21st century - the approach of the WHO Global Oral Health Programme. Geneva: World Health Organisation, 2003.

2. Selwitz RH, Ismail AI, Pitts NB. Dental caries. Lancet 2007; 369: 51-9.

3. Sheiham A. Dental caries affects body weight, growth and quality of life in pre-school children. Br Dent J 2006; 201: 625-6.

4. Casamassimo PS, Thikkurissy S, Edelstein BL, Maiorini E. Beyond the dmft: the human and economic cost of early childhood caries. J Am Dent Assoc 2009; 140: 650-7.

5. Gionet L. Breastfeeding trends in Canada. Health at a Glance. Canada: Statistics Canada Catalogue no. 82-624-X, 2013.

6. Madan C, Kruger E, Perera I, Tennant M. Trends in demand for general anaesthetic care for paediatric caries in Western Australia: geographic and socio-economic modelling of service utilisation. Int Dent J 2010; 60: 190-6.

7. Takahashi N, Nyvad B. The role of bacteria in the caries process: ecological perspectives. J Dent Res 2011; 90: 294-303.

8. Tanzer J, Livingston J, Thompson A. The microbiology of primary dental caries in humans. J Dent Educ 2001; 65: 1028-37.

9. Danielsson Niemi L, Hernell O, Johansson I. Human milk compounds inhibiting adhesion of mutans streptococci to host ligand-coated hydroxyapatite in vitro. Caries Res 2009; 43: 171-8.

10. Holgerson PL, Vestman NR, Claesson R, Ohman C, Domellof $\mathrm{M}$, Tanner AC, et al. Oral microbial profile discriminates breast-fed from formula-fed infants. I Pediatr Gastroenterol Nutr 2013; 56: 127-36.

11. The American Dental Association. Tooth eruption: the primary teeth. I Am Dent Assoc 2005; 136: 1619.

12. World Health Organization. Infant and young child feeding. Fact Sheet No 342. Available at: http:// www.who.int/mediacentre/factsheets/fs342/en/February 2004. (accessed on 10th April 2015).

13. unicef GLOBAL DATABASES. Infant and young child feeding. In: data.unicef.org, editor. Available at: http://data.unicef.org/nutrition/iycf. (accessed on April 30, 2015) October 2014

14. Li R, Fein SB, Chen J, Grummer-Strawn LM. Why mothers stop breastfeeding: mothers' self-reported reasons for stopping during the first year. Pediatrics 2008; 122: (Suppl 2): S69-76.

15. Australian Institute of Health and Welfare. 2010 Australian national infant feeding survey: indicator results. Canberra, Australia: AIHW, 2011.

16. Department of Health. Breastfeeding. Available at: http:// www.health.gov.au/breastfeeding: Australian Government Department of Health. (accessed on 11th April 2015).

17. Valaitis R, Hesch R, Passarelli C, Sheehan D, Sinton J. A systematic review of the relationship between breastfeeding and early childhood caries. Can J Public Health 2000; 91: 411-7.

18. Salone LR, Vann WF, Dee DL. Breastfeeding: an overview of oral and general health benefits. J Am Dent Assoc 2013; 144 : 143-51.

19. White V. Breastfeeding and the risk of early childhood caries. Evid Based Dent 2008; 9: 86-8.

20. Ribeiro NM, Ribeiro MA. Breastfeeding and early childhood caries: a critical review. J Pediatr 2004; 80: S199-210.

21. Leong PM, Gussy MG, Barrow SY, de Silva-Sanigorski A, Waters E. A systematic review of risk factors during first year of life for early childhood caries. Int J Paediatr Dent 2013; 23: 235-50.

22. Wells G, Shea B, O'Connell D, Peterson J, Welch V, Losos M, et al. The Newcastle-Ottawa Scale (NOS) for assessing the quality of nonrandomised studies in meta-analyses. http:// www.ohri.ca/programs/clinical_epidemiology/oxford.asp. (accessed on 30th November 2014).

23. Guyatt GH, Oxman AD, Vist G, Kunz R, Brozek J, AlonsoCoello P, et al. GRADE guidelines: 4. Rating the quality of evidence-study limitations (risk of bias). J Clin Epidemiol 2011; 64: 407-15.

24. PRISMA. PRISMA Statement - preferred reporting items for systematic reviews and meta-analyses. www.prismastatement.org/. Accessed 30th November 2014

25. Feldens CA, Giugliani ERJ, Vigo A, Vítolo MR. Early feeding practices and severe early childhood caries in four-year-old children from southern Brazil: a birth cohort study. Caries Res 2010; 44: 445-52.

26. Chaffee BW, Feldens CA, Vitolo MR. Association of longduration breastfeeding and dental caries estimated with marginal structural models. Ann Epidemiol 2014; 24: 448-54.

27. Feldens CA, Giugliani ER, Duncan BB, Drachler Mde L, Vitolo MR. Long-term effectiveness of a nutritional program in reducing early childhood caries: a randomized trial. Community Dent Oral Epidemiol 2010; 38: 324-32.

28. Kramer MS, Matush L, Bogdanovich N, Aboud F, Mazer B, Fombonne E, et al. Health and development outcomes in 6.5y-old children breastfed exclusively for 3 or 6 mo. Am J Clin Nutr 2009; 90: 1070-4.

29. Kramer MS, Vanilovich I, Matush L, Bogdanovich N, Zhang X, Shishko G, et al. The effect of prolonged and exclusive breastfeeding on dental caries in early school-age children. Caries Res 2007; 41: 484-8. 
30. Feldens CA, Vítolo MR, Drachler Mde L. A randomized trial of the effectiveness of home visits in preventing early childhood caries. Community Dent Oral Epidemiol 2007; 35: 215-23.

31. Hong L, Levy SM, Warren JJ, Broffitt B. Infant breast-feeding and childhood caries: a nine-year study. Pediatr Dent 2014; 36: 342-7.

32. Silver DH. A longitudinal study of infant feeding practice, diet and caries, related to social class in children aged 3 and 8 10 years. Br Dent J 1987; 163: 296-300.

33. Tada A, Ando Y, Hanada N. Caries risk factors among threeyear old children in Chiba, Japan. Asia Pac J Public Health 1999; 11: 109-12.

34. Tanaka K, Miyake Y, Sasaki S, Hirota Y. Infant feeding practices and risk of dental caries in Japan: the Osaka Maternal and Child Health Study. Pediatr Dent 2013; 35: 267-71.

35. Thitasomakul S, Piwat S, Thearmontree A, Chankanka O, Pithpornchaiyakul W, Madyusoh S. Risks for early childhood caries analyzed by negative binomial models. J Dent Res 2009; 88: $137-41$

36. van Palenstein Helderman WH, Soe W, van't Hof MA. Risk factors of early childhood caries in a Southeast Asian population. J Dent Res 2006; 85: 85-8.

37. Yonezu T, Ushida N, Yakushiji M. Longitudinal study of prolonged breast- or bottle-feeding on dental caries in Japanese children. Bull Tokyo Dent Coll 2006; 47: 157-60.

38. Ollila P, Larmas M. A seven-year survival analysis of caries onset in primary second molars and permanent first molars in different caries risk groups determined at age two years. Acta Odontol Scand 2007; 65: 29-35.

39. Bahuguna R, Younis Khan S, Jain A. Influence of feeding practices on dental caries. A case-control study. Eur J Paediatr Dent 2013; 14: 55-8.

40. Matee M, van't Hof M, Maselle S, Mikx F, van Palenstein Helderman W. Nursing caries, linear hypoplasia, and nursing and weaning habits in Tanzanian infants. Community Dent Oral Epidemiol 1994; 22: 289-93.

41. Roberts GJ, Cleaton-Jones PE, Fatti LP, Richardson BD, Sinwel RE, Hargreaves JA, et al. Patterns of breast and bottle feeding and their association with dental caries in 1- to 4-year-old South African children. 2. A case control study of children with nursing caries. Community Dent Health 1994; 11: 38-41.

42. Alaluusua S, Myllarniemi S, Kallio M, Salmenpera L, Tainio VM. Prevalence of caries and salivary levels of mutans streptococci in 5-year-old children in relation to duration of breast feeding. Scand J Dent Res 1990; 98: 193-6.

43. al-Dashti AA, Williams SA, Curzon ME. Breast feeding, bottle feeding and dental caries in Kuwait, a country with lowfluoride levels in the water supply. Community Dent Health 1995; 12: 42-7.

44. Azevedo TD, Bezerra AC, de Toledo OA. Feeding habits and severe early childhood caries in Brazilian preschool children. Pediatr Dent 2005; 27: 28-33.

45. Campus G, Solinas G, Strohmenger L, Cagetti MG, Senna A, Minelli L, et al. National pathfinder survey on children's oral health in Italy: pattern and severity of caries disease in 4-yearolds. Caries Res 2009; 43: 155-62.

46. Cariño KMG, Shinada K, Kawaguchi Y. Early childhood caries in northern Philippines. Community Dent Oral Epidemiol 2003; 31: 81-9.

47. Dini EL, Holt RD, Bedi R. Caries and its association with infant feeding and oral health-related behaviours in 3-4-year-old Brazilian children. Community Dent Oral Epidemiol 2000; 28: 241-8.

48. Du M, Bian Z, Guo L, Holt R, Champion J, Bedi R. Caries patterns and their relationship to infant feeding and socio- economic status in 2-4-year-old Chinese children. Int Dent J 2000; 50: 385-9.

49. Dye BA, Shenkin JD, Ogden CL, Marshall TA, Levy SM, Kanellis MJ. The relationship between healthful eating practices and dental caries in children aged $2-5$ years in the United States, 1988-1994. J Am Dent Assoc 2004; 135: 5566.

50. Folayan MO, Sowole CA, Owotade FJ, Sote E. Impact of infant feeding practices on caries experience of preschool children. $J$ Clin Pediatr Dent 2010; 34: 297-301.

51. Forsman B, Ericsson Y. Breastfeeding, formula feeding and dental health in low-fluoride districts in Sweden. Community Dent Oral Epidemiol 1974; 2: 1-6.

52. Hallett KB, O'Rourke PK. Social and behavioural determinants of early childhood caries. Aust Dent J 2003; 48: 27-33.

53. Hallonsten AL, Wendt LK, Mejare I, Birkhed D, Hakansson C, Lindvall AM, et al. Dental caries and prolonged breast-feeding in 18-month-old Swedish children. Int J Paediatr Dent 1995; 5: 149-55.

54. Haq ME, Begum K, Muttalib MA, Shahidullah M. Prevalence of caries in urban children and its relation to feeding pattern. Bangladesh Med Res Counc Bull 1985; 11: 55-63.

55. Hardy NR. The effect of breast feeding in infancy on the D.M.F. ratio of deciduous canine and molar teeth in children below seven years of age. Apex 1978; 10: 7-8.

56. Harrison R, Wong T, Ewan C, Contreras B, Phung Y. Feeding practices and dental caries in an urban Canadian population of Vietnamese preschool children. ASDC J Dent Child 1997; 64: 112-7.

57. Holt RD, Joels D, Winter GB. Caries in pre-school children The Camden study. Br Dent J 1982; 153: 107-9.

58. Hong CHL, Bagramian RA, Hashim Nainar SM, Straffon LH, Shen L, Hsu C-YS. High caries prevalence and risk factors among young preschool children in an urban community with water fluoridation. Int J Pediatr Dent 2014; 24: 32-42.

59. Iida $\mathrm{H}$, Auinger $\mathrm{P}$, Billings RJ, Weitzman M. Association between infant breastfeeding and early childhood caries in the United States. Pediatrics 2007; 120: e944-52.

60. Johansson I, Holgerson PL, Kressin NR, Nunn ME, Tanner AC. Snacking habits and caries in young children. Caries Res 2010; 44: 421-30.

61. Livny A, Assali R, Sgan-Cohen HD. Early Childhood Caries among a Bedouin community residing in the eastern outskirts of Jerusalem. BMC Public Health 2007; 7: 167.

62. Majorana A, Cagetti MG, Bardellini E, Amadori F, Conti G, Strohmenger L, et al. Feeding and smoking habits as cumulative risk factors for early childhood caries in toddlers, after adjustment for several behavioral determinants: a retrospective study. BMC Pediatr 2014; 14: 1471-2431.

63. Masumo R, Bardsen A, Mashoto K, Astrom AN. Prevalence and socio-behavioral influence of early childhood caries, ECC, and feeding habits among 6-36 months old children in Uganda and Tanzania. BMC Oral Health 2012; 12: 1472 6831.

64. Mattos-Graner RO, Zelante F, Line R, Mayer MPA Association between caries prevalence and clinical, microbiological and dietary variables in 1.0 to 2.5 -year-old Brazilian children. Caries Res 1998; 32: 319-23.

65. Nobile CG, Fortunato L, Bianco A, Pileggi C, Pavia M. Pattern and severity of early childhood caries in Southern Italy: a preschool-based cross-sectional study. BMC Public Health 2014; 14: 1471-2458.

66. Nunes AMM, Alves CMC, Araújo F, Ortiz TML, Ribeiro MRC, Silva AAMD, et al. Association between prolonged breastfeeding and early childhood caries: a hierarchical approach. Community Dent Oral Epidemiol 2012; 40: 542-9. 
67. Perera PJ, Fernando MP, Warnakulasooriya TD, Ranathunga $\mathrm{N}$. Effect of feeding practices on dental caries among preschool children: a hospital based analytical cross sectional study. Asia Pac J Clin Nutr 2014; 23: 272-7.

68. Prakash P, Subramaniam P, Durgesh BH, Konde S. Prevalence of early childhood caries and associated risk factors in preschool children of urban Bangalore, India: a cross-sectional study. Eur J Dent 2012; 6: 141-52.

69. Prakasha Shrutha S, Vinit GB, Giri KY, Alam S. Feeding practices and early childhood caries: a cross-sectional study of preschool children in kanpur district, India. ISRN Dent 2013; 5: 275193. doi: 10.1155/2013/275193. eCollection 2013.

70. Qadri G, Nourallah A, Splieth CH. Early childhood caries and feeding practices in kindergarten children. Quintessence Int 2012; 43: 503-10.

71. Retnakumari N, Cyriac G. Childhood caries as influenced by maternal and child characteristics in pre-school children of Kerala - an epidemiological study. Contemp Clin Dent 2012; 3: 2-8.

72. Rosenblatt A, Zarzar P. Breast-feeding and early childhood caries: an assessment among Brazilian infants. Int J Pediatr Dent 2004; 14: 439-45.

73. Sankeshwari RM, Ankola AV, Tangade PS, Hebbal MI. Feeding habits and oral hygiene practices as determinants of early childhood caries in 3- to 5-year-old children of Belgaum City, India. Oral Health Prev Dent 2012; 10: 283-90.

74. Santos AP, Soviero VM. Caries prevalence and risk factors among children aged 0 to 36 months. Pesqui Odontol Bras 2002; 16: 203-8.

75. Sayegh A, Dini EL, Holt RD, Bedi R. Caries prevalence and patterns and their relationship to social class, infant feeding and oral hygiene in 4-5-year-old children in Amman, Jordan. Community Dent Health 2002; 19: 144-51.

76. Sayegh A, Dini EL, Holt RD, Bedi R. Oral health, sociodemographic factors, dietary and oral hygiene practices in Jordanian children. J Dent 2005; 33: 379-88.

77. Serwint JR, Mungo R, Negrete VF, Duggan AK, Korsch BM. Child-rearing practices and nursing caries. Pediatrics 1993; 92: 233-7.

78. Slabsinskiene E, Milciuviene S, Narbutaite J, Vasiliauskiene I, Andruskeviciene V, Bendoraitiene EA, et al. Severe early childhood caries and behavioral risk factors among 3-year-old children in Lithuania. Medicina (Kaunas) 2010; 46: 135-41.

79. Songo BF, Declerck D, Vinckier F, Mbuyi MD, Pilipili CM, Kayembe KP. Caries experience and related factors in 4
6 year-olds attending dental clinics in Kinshasa, DR of Congo. Community Dent Health 2013; 30: 257-62.

80. Tanaka K, Miyake Y. Association between breastfeeding and dental caries in Japanese children. J Epidemiol 2012; 22: 72-7.

81. Tiano AV, Moimaz SA, Saliba O, Saliba NA. Dental caries prevalence in children up to 36 months of age attending daycare centers in municipalities with different water fluoride content. J Appl Oral Sci 2009; 17: 39-44.

82. Tyagi R. The prevalence of nursing caries in Davangere preschool children and its relationship with feeding practices and socioeconomic status of the family. J Indian Soc Pedod Prev Dent 2008; 26: 153-7.

83. Vachirarojpisan T, Shinada K, Kawaguchi Y, Laungwechakan P, Somkote T, Detsomboonrat P. Early childhood caries in children aged 6-19 months. Community Dent Oral Epidemiol 2004; 32: 133-42.

84. Vazquez-Nava F, Vazquez RE, Saldivar GA, Beltran GF, Almeida AV, Vazquez RC. Allergic rhinitis, feeding and oral habits, toothbrushing and socioeconomic status. Effects on development of dental caries in primary dentition. Caries Res 2008; 42: 141-7.

85. Wendt LK, Birkhed D. Dietary habits related to caries development and immigrant status in infants and toddlers living in Sweden. Acta Odontol Scand 1995; 53: 339-44.

86. Yonezu T, Yotsuya K, Yakushiji M. Characteristics of breastfed children with nursing caries. Bull Tokyo Dent Coll 2007; 47: 161-5.

87. The World Bank. Available at: http://www.worldbank.org/. http://www.worldbank.org/. (accessed on 20th Feb 2015).

88. Vadiakas G. Case definition, aetiology and risk assessment of early childhood caries (ECC): a revisited review. Eur Arch Paediatr Dent 2008; 9: 114-25.

89. Kerr CA, Grice DM, Tran CD, Bauer DC, Li D, Hendry P, et al. Early life events influence whole-of-life metabolic health via gut microflora and gut permeability. Crit Rev Microbiol. 2015; 2015: 326-40.

90. Peres RC, Coppi LC, Volpato MC, Groppo FC, Cury JA, Rosalen PL. Cariogenic potential of cows', human and infant formula milks and effect of fluoride supplementation. Br J Nutr 2009; 101: 376-82.

91. Bowen WH, Lawrence RA. Comparison of the cariogenicity of cola, honey, cow milk, human milk, and sucrose. Pediatrics 2005; 116: 921-6. 


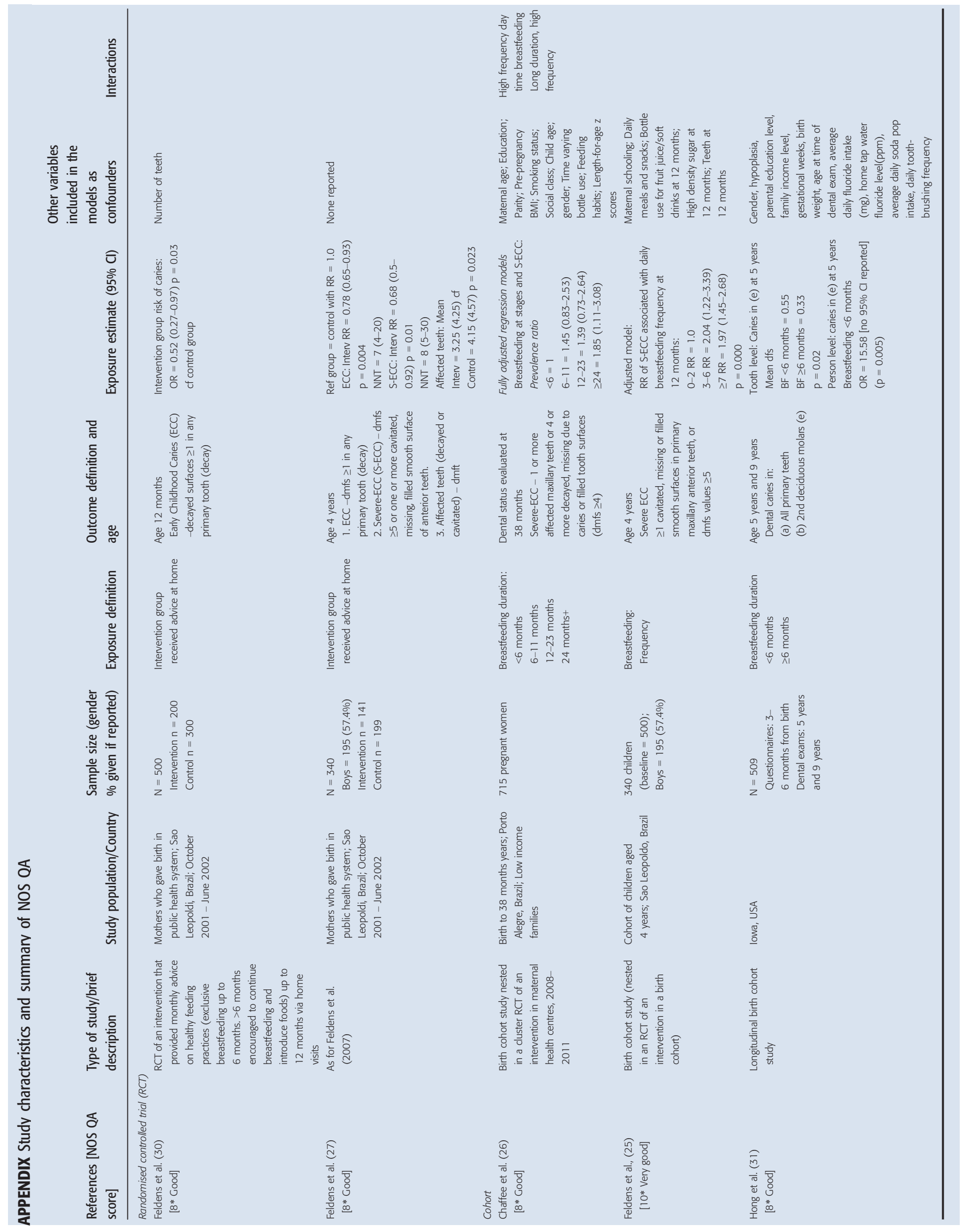




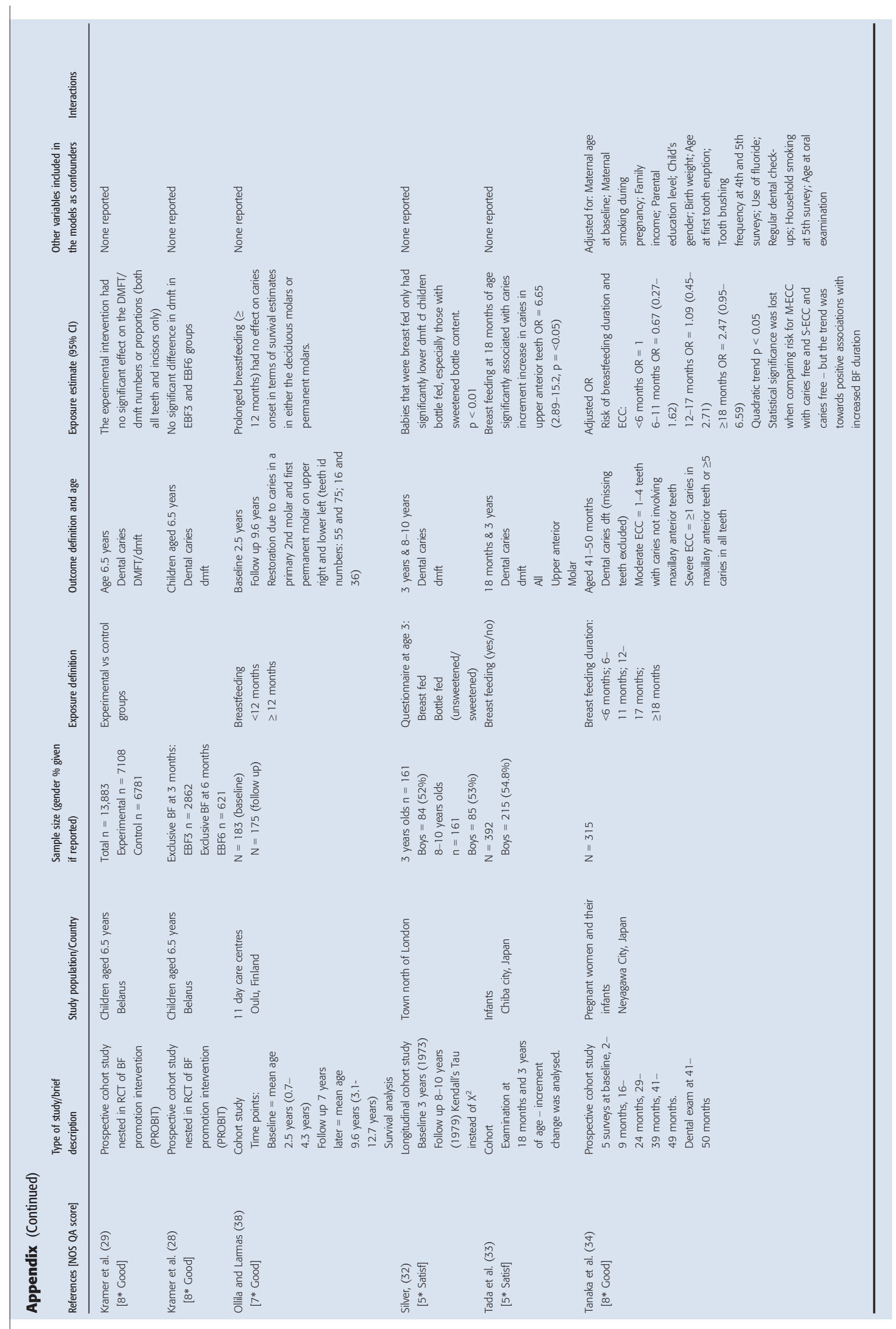




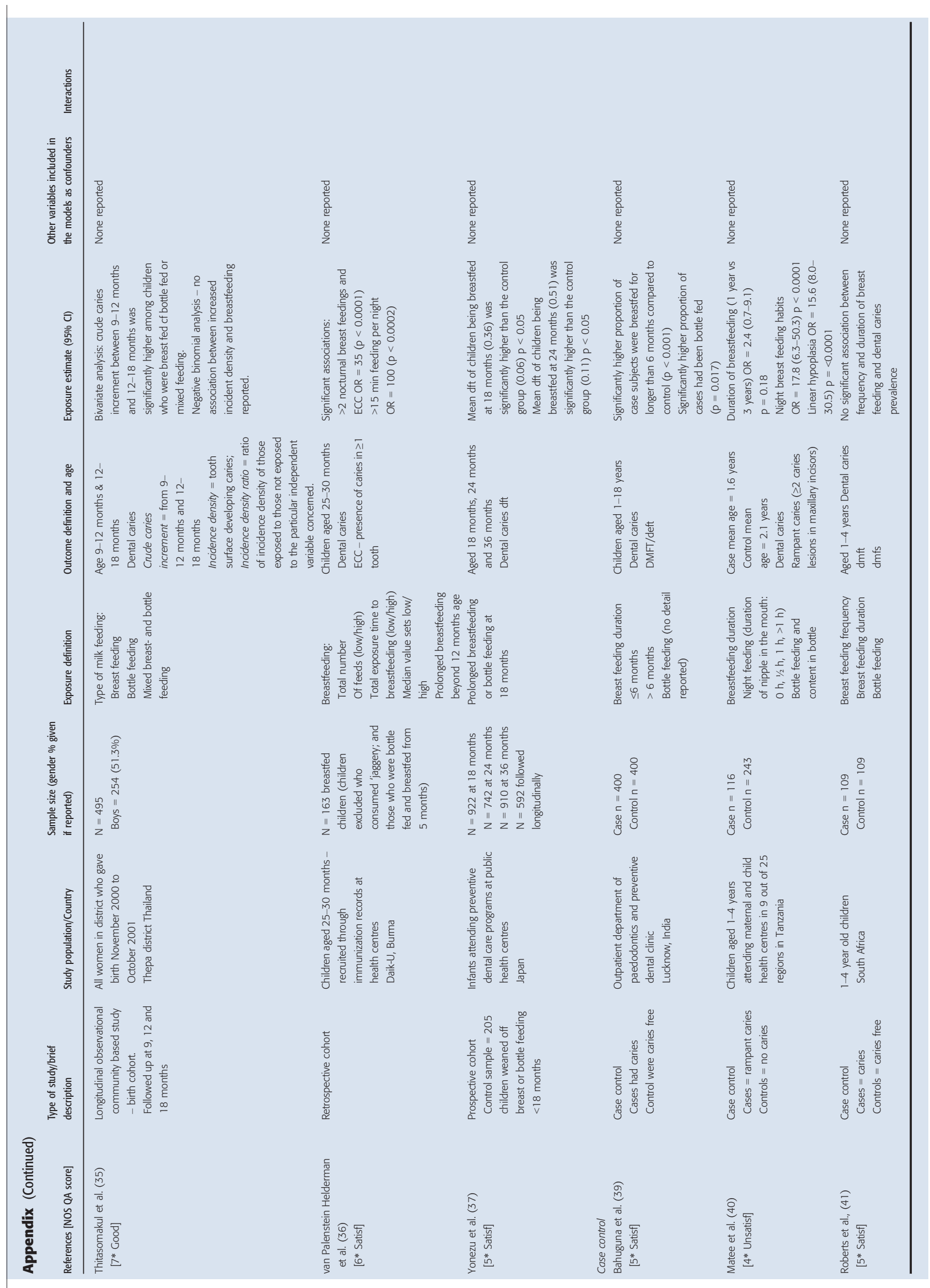




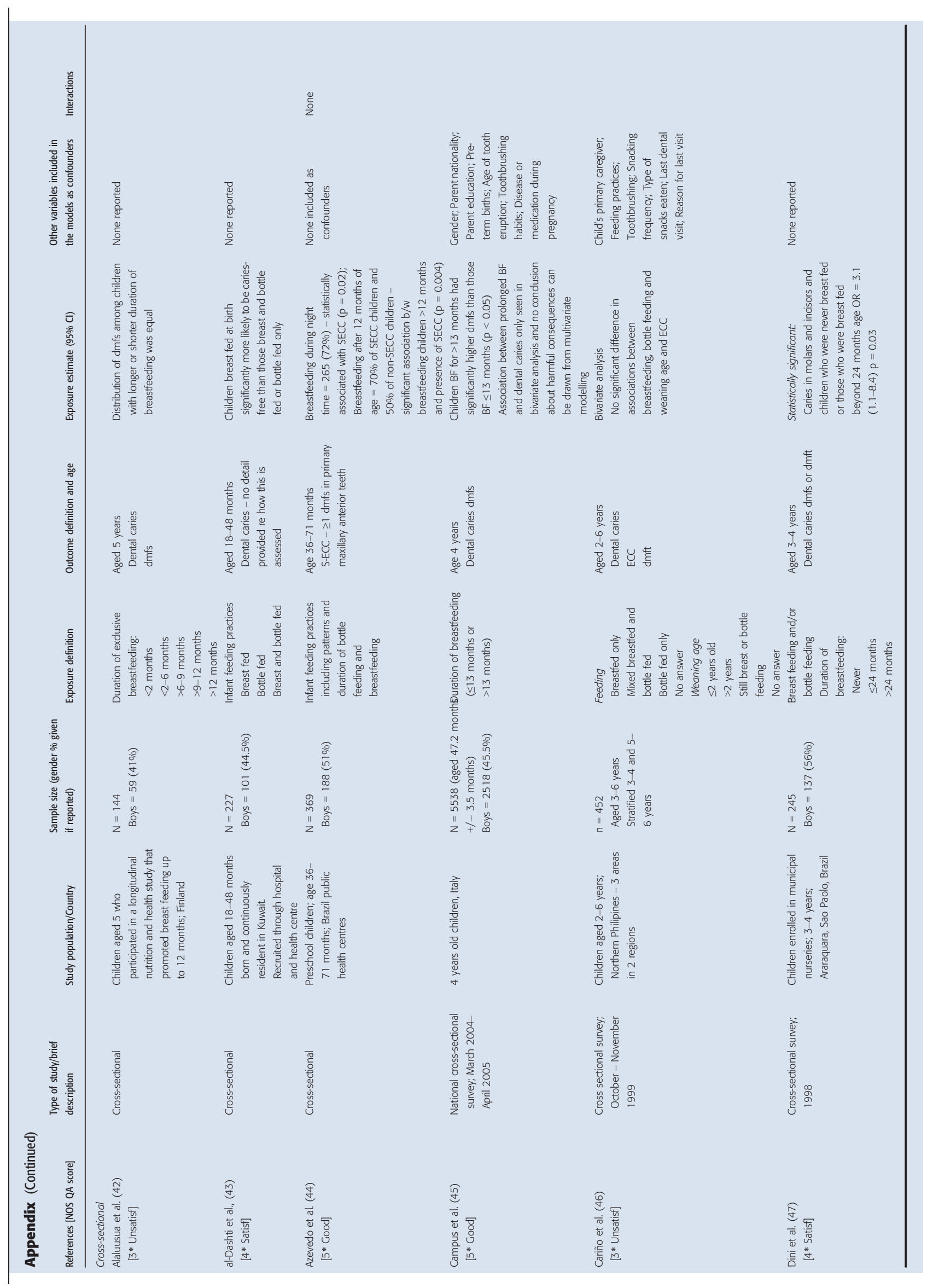




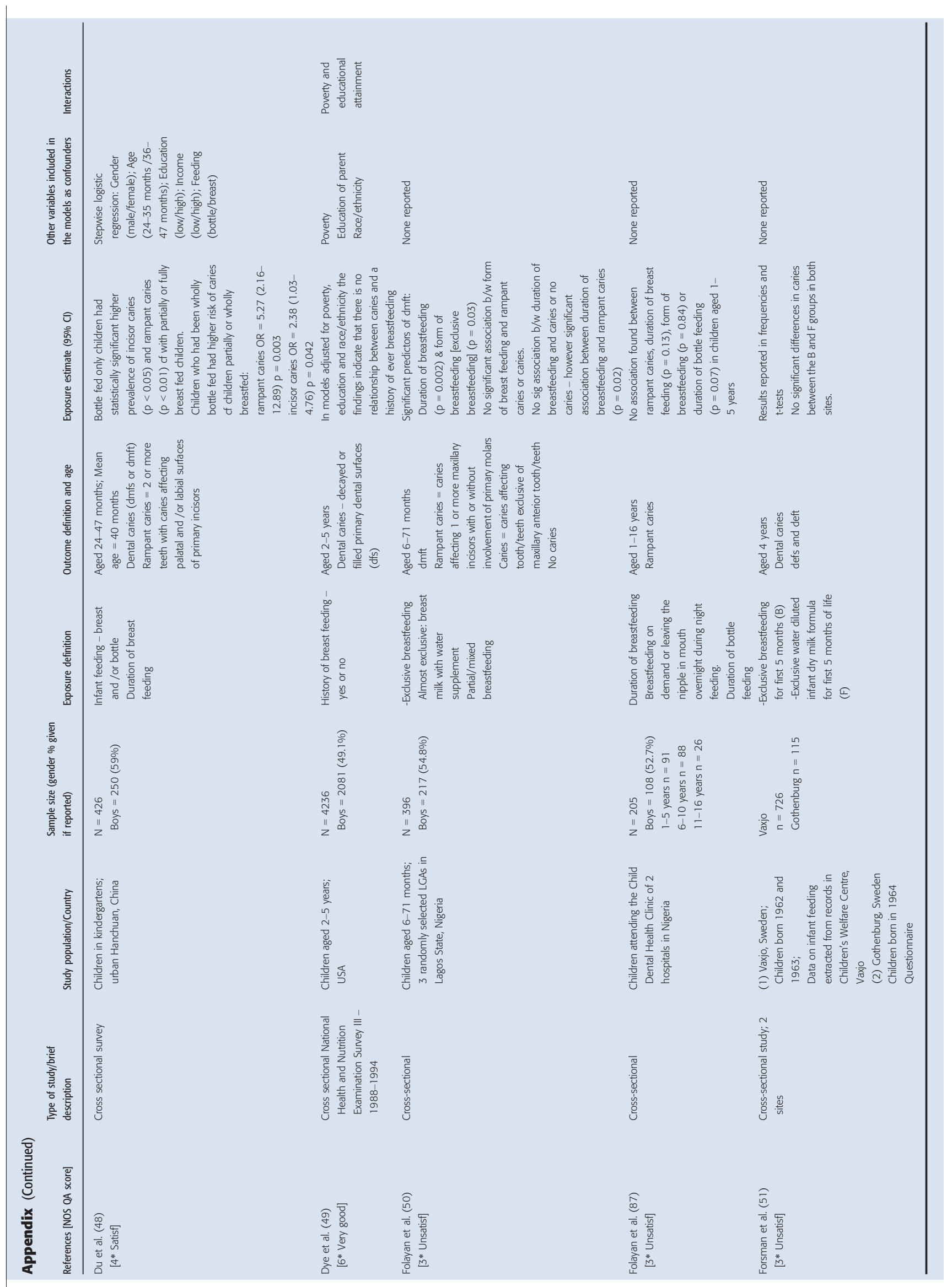




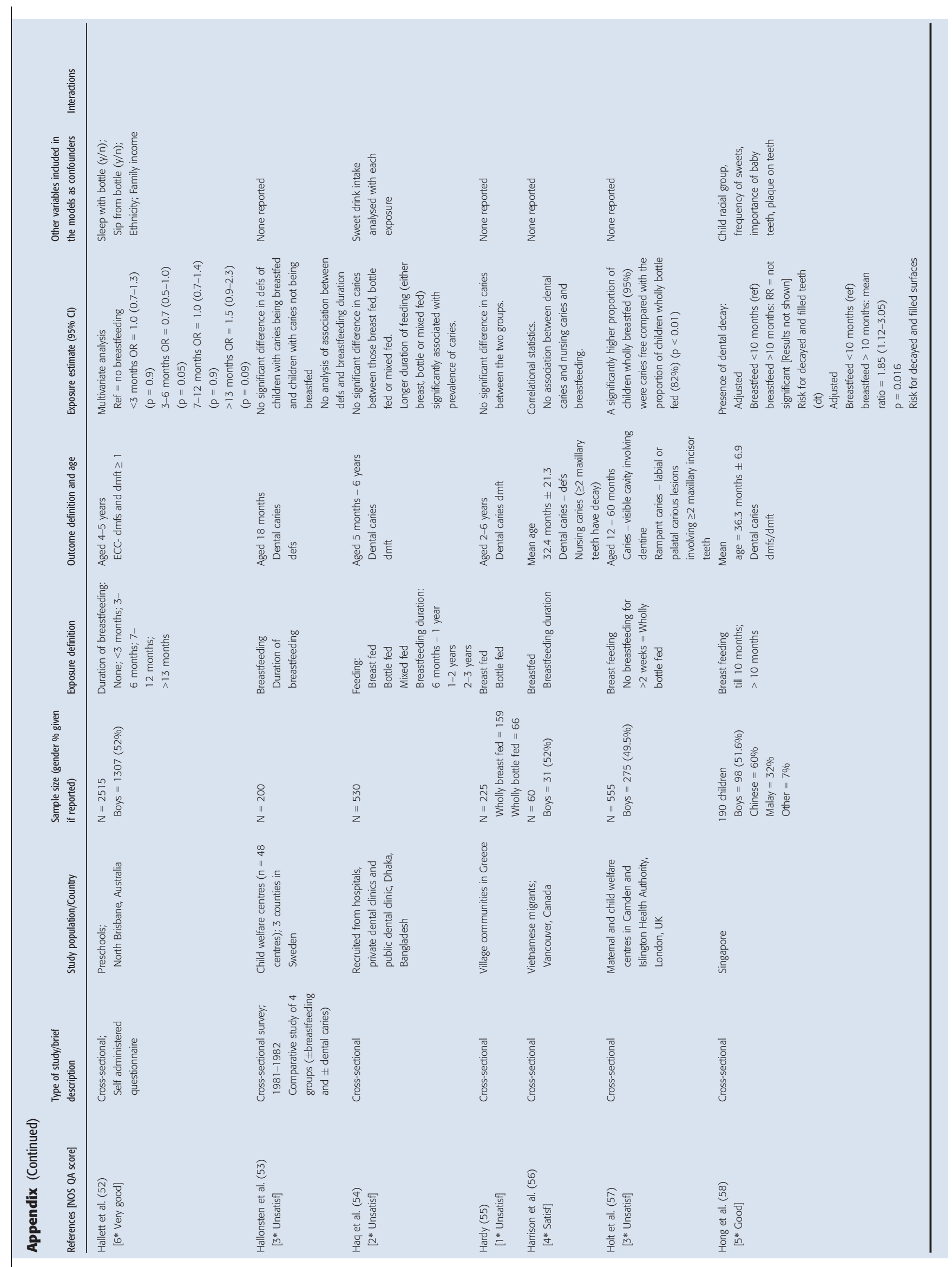




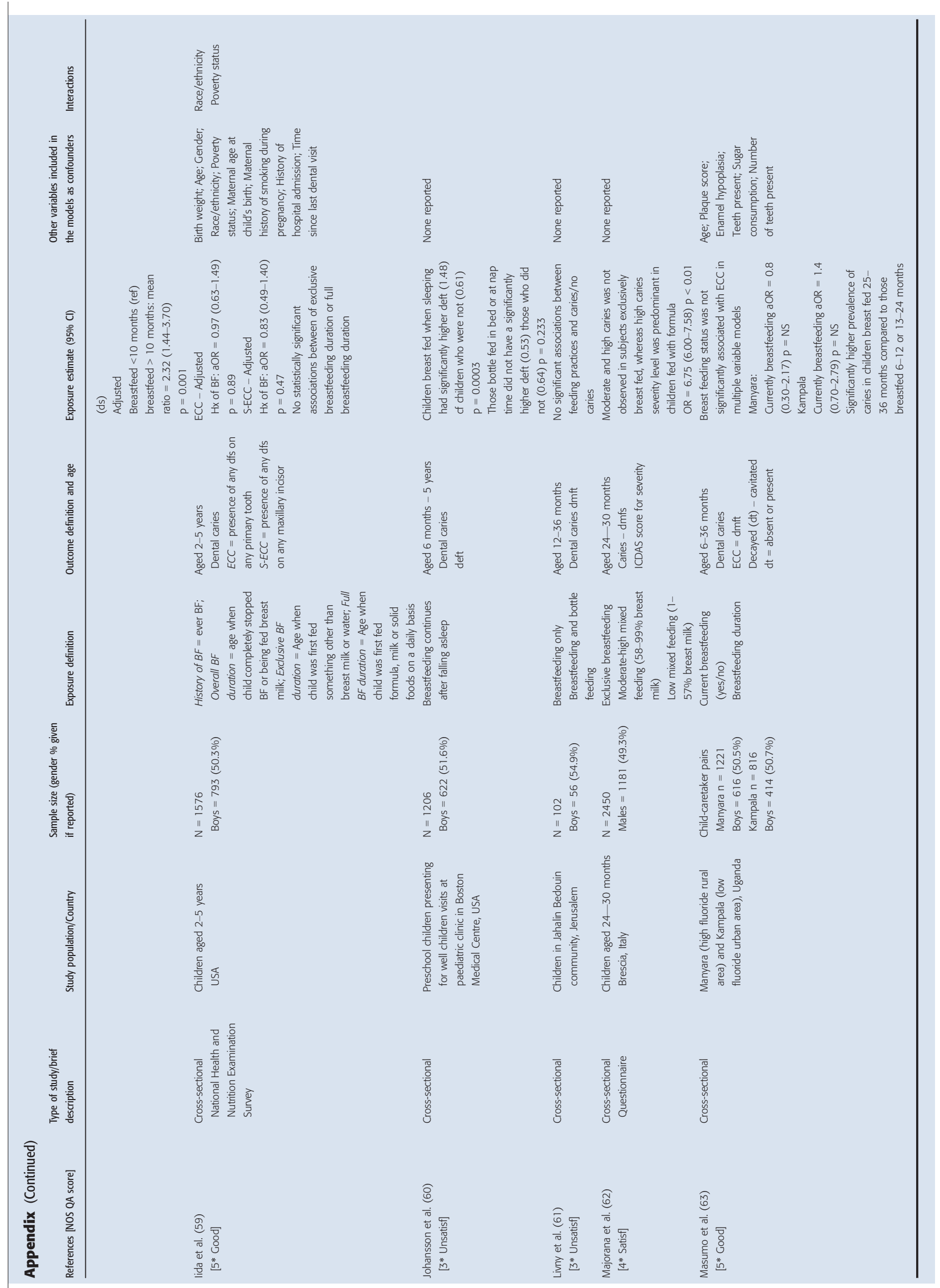




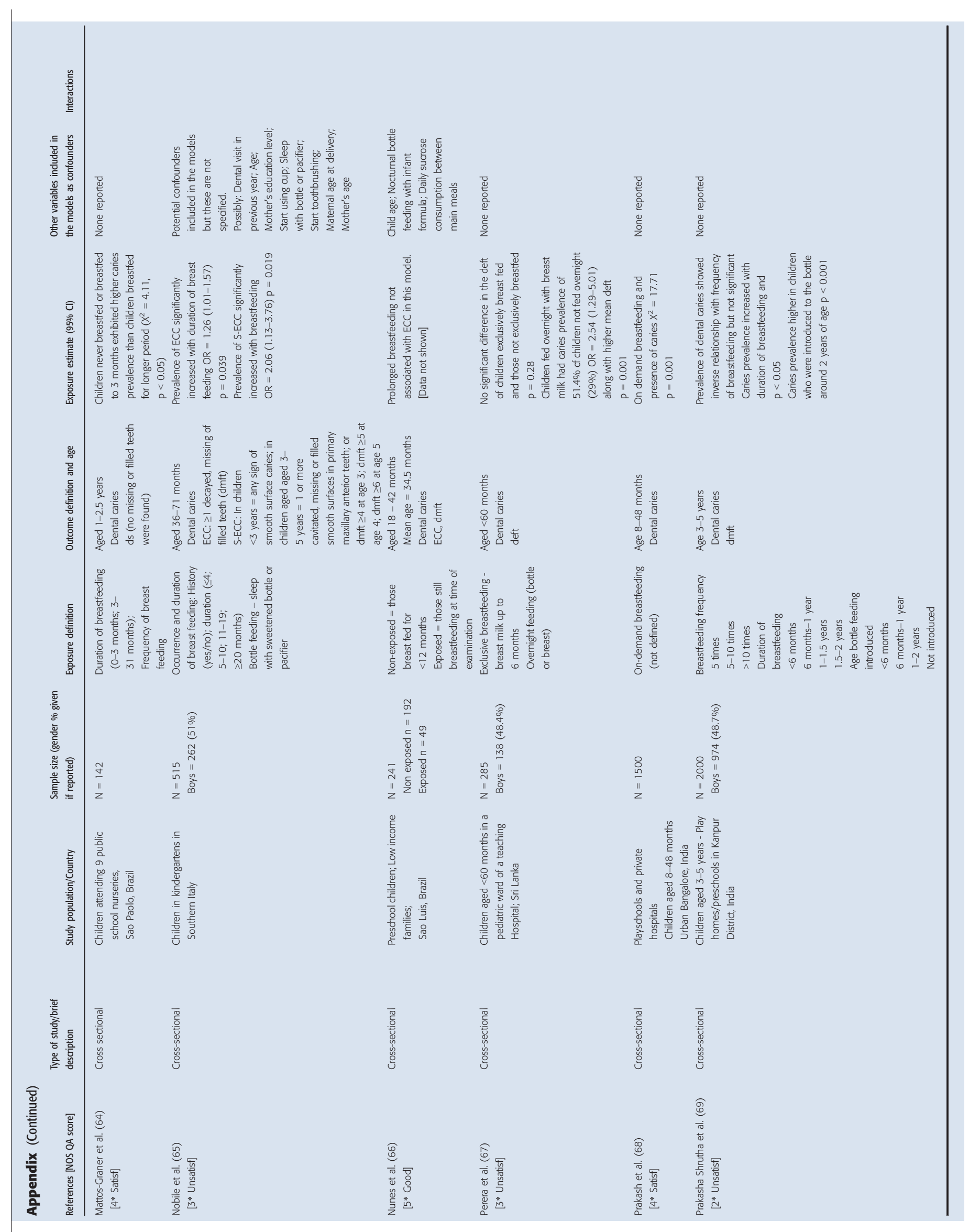




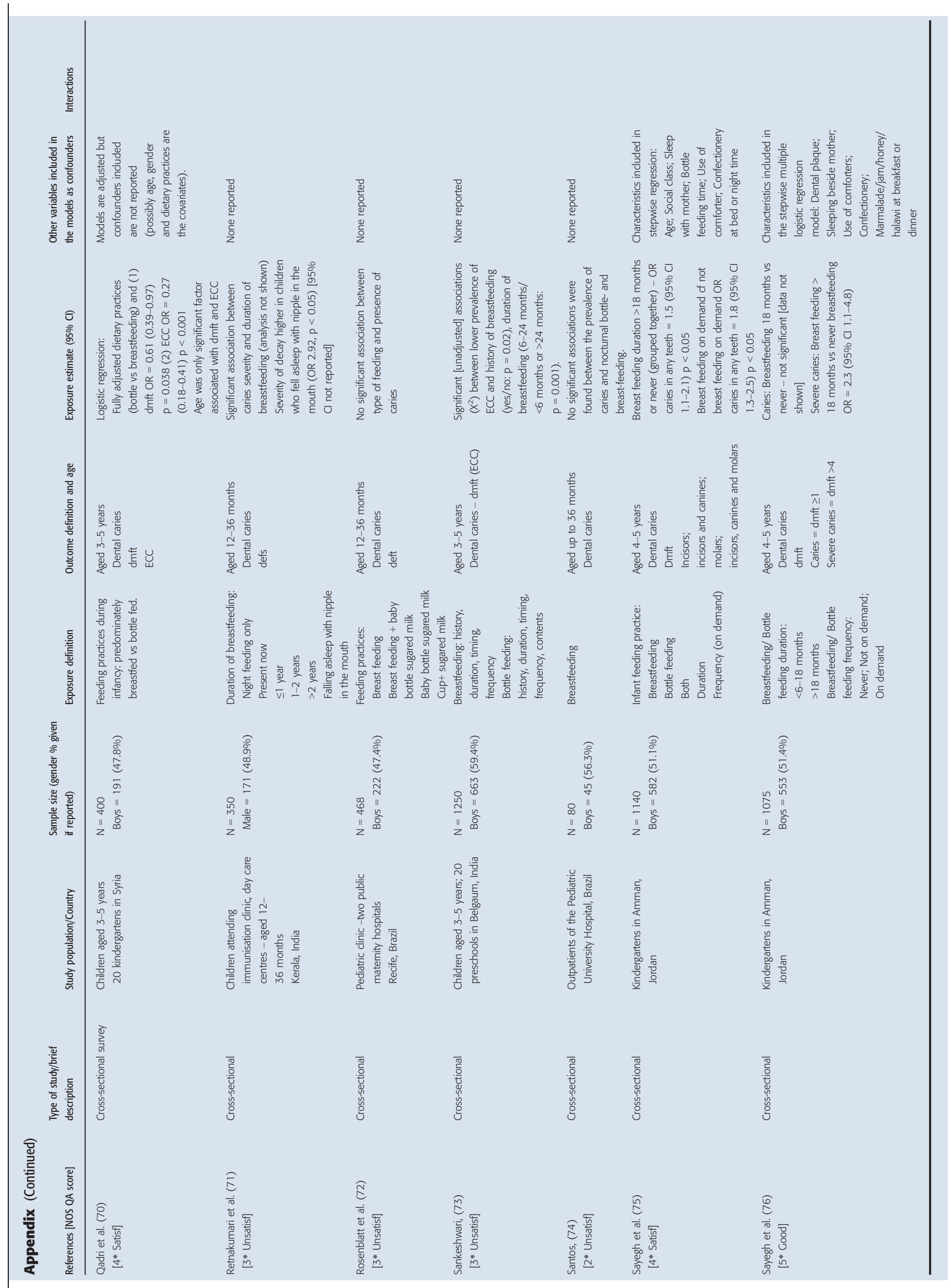




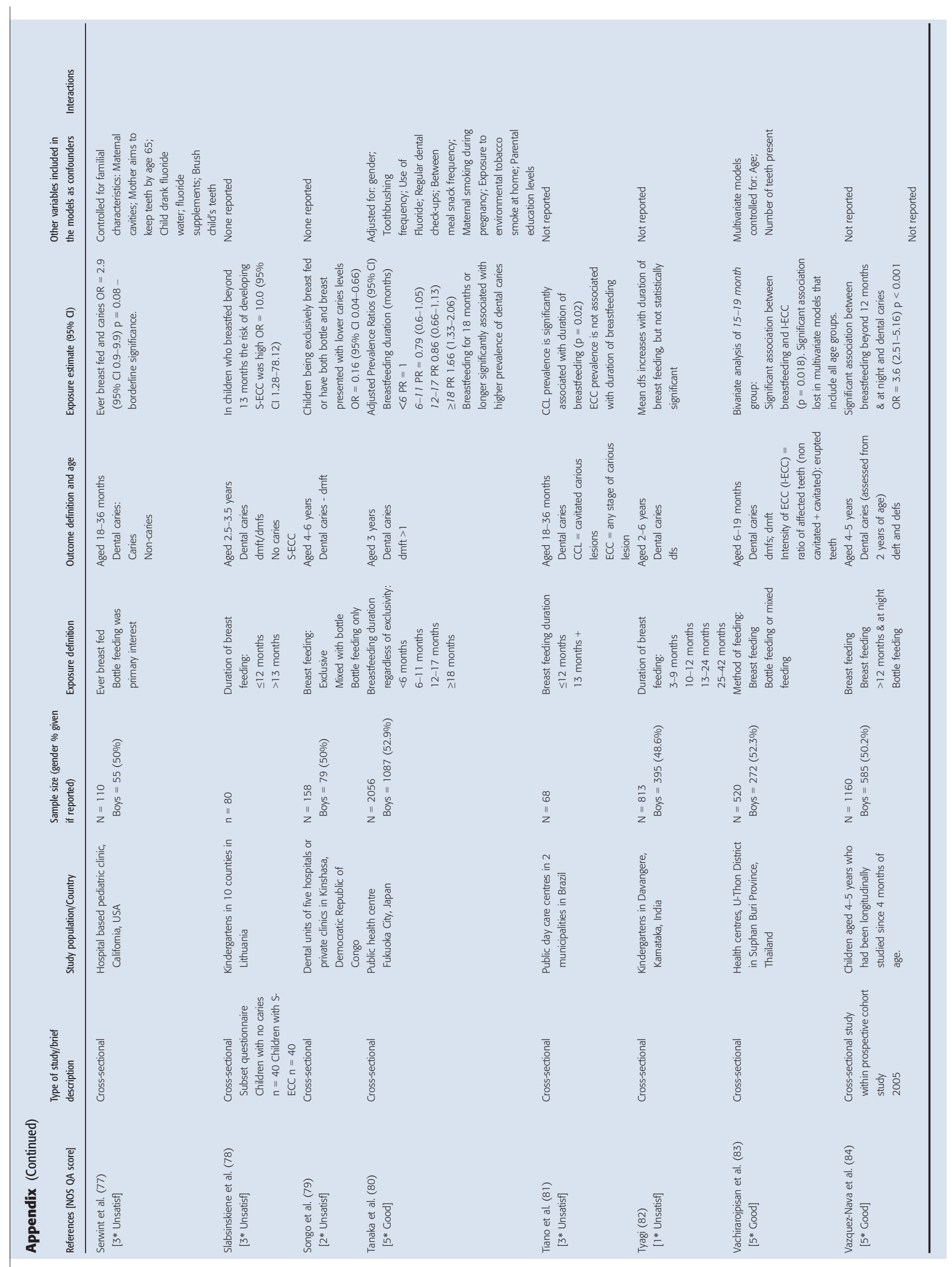




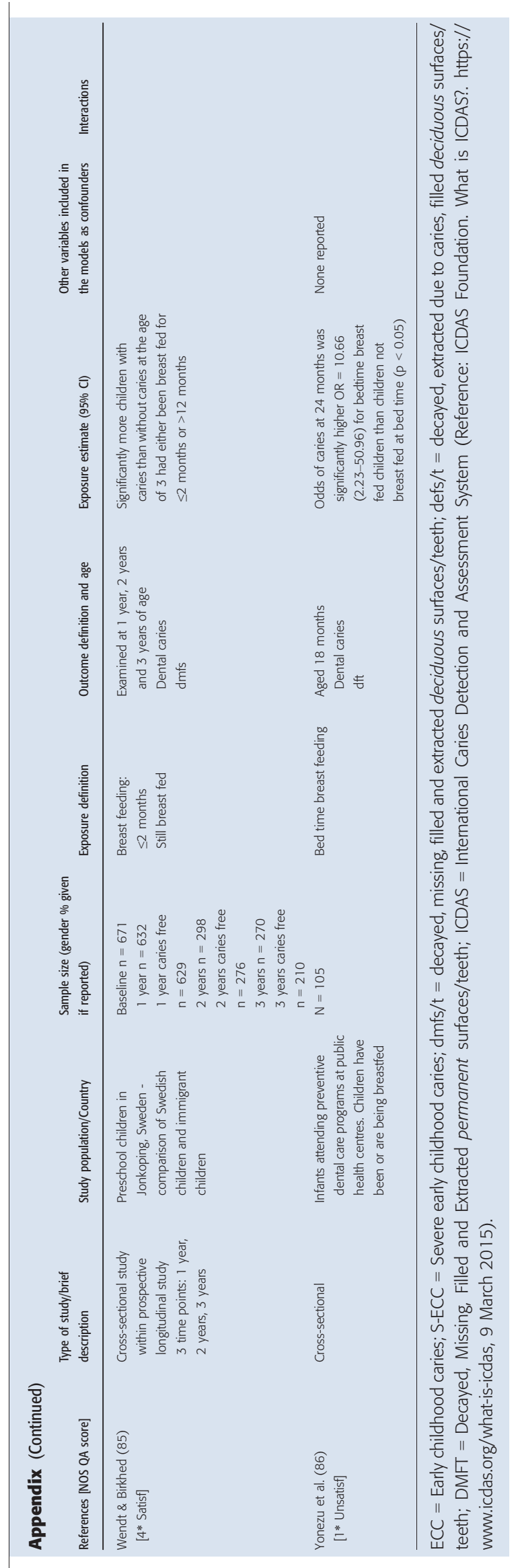

